INSTITUTO DE PSICOLOGIA

André Maurício Passos Liber

\title{
Análise de células bipolares PKCo-IR e células ganglionares da retina do peixe tropical Hoplias malabaricus intoxicado com baixas doses agudas de metilmercúrio \\ (Versão Corrigida)
}

SÃO PAULO

2011 


\section{INSTITUTO DE PSICOLOGIA}

CURSO DE PÓS-GRADUAÇÃO

\section{Análise de células bipolares PKC $\alpha$-IR e células ganglionares da retina do peixe tropical Hoplias malabaricus intoxicado com baixas doses agudas de metilmercúrio \\ (Versão Corrigida)}

André Maurício Passos Liber

Orientadora: Porf ${ }^{a}$ Dra. Dora Selma Fix Ventura

Dissertação apresentada ao Programa de Neurociências

e Comportamento do Instituto de Psicologia da Universidade de São Paulo, para obtenção do grau de Mestre em Psicologia. 
Liber, André Maurício Passos.

Análise de células bipolares PKC $\alpha$-IR e células ganglionares da retina do peixe tropical Hoplias malabaricus intoxicado com baixas doses agudas de metilmercúrio / André Maurício Passos Liber; orientadora Dora Selma Fix Ventura. -- São Paulo, 2011.

$75 \mathrm{f}$.

Dissertação (Mestrado - Programa de Pós-Graduação em Psicologia. Área de Concentração: Neurociências e Comportamento) Instituto de Psicologia da Universidade de São Paulo.

1. Retina 2. Células bipolares da retina 3. Células ganglionares da retina 4. Compostos de metilmercúrio 5. Acuidade visual 6. Peixes I. Título.

QP479 


\section{FOLHA DE APROVAÇÃO}

\section{André Mauricio Passos Liber}

"Análise de células bipolares PKC $\alpha$-IR e células ganglionares da retina do peixe tropical Hoplias malabaricus intoxicado com baixas doses agudas de metilmercúrio"

Dissertação apresentada ao Instituto de Psicologia da Universidade de São Paulo, para obtenção do título de Mestrado.

Área de Concentração: Neurociências e Comportamento.

Dissertação defendida e aprovada em: / /

\section{BANCA EXAMINADORA}

Examinador (a) Assinatura

Nome

Instituição

Examinador (a) Assinatura

Nome

Instituição

Examinador (a) Assinatura

Nome

Instituição 
Dedico este trabalho aos meus Pais, por todo carinho e suporte a mim dado durante toda a minha existência e por todo o apoio, auxilio e força empenhada para que eu pudesse completar mais uma etapa da minha vida. Obrigado! 


\section{Agradecimentos}

Agradeço a professora Dr ${ }^{\mathrm{a}}$. Dora Fix Ventura, minha orientadora, pela oportunidade de realização desde trabalho, por sua orientação e ensinamentos que transpassam as paredes do laboratório.

A todos os constituintes do laboratório de Psicofisiologia Sensorial e do Laboratório da Visão, que dão vida a este grupo que muitas vezes se tornar nossa família, devido ao extenso convívio e interação, um obrigado a todos que fazem parte da família Labvis. Em especial agradeço a Daniela Bonci, Gabriela Ioshimoto, Sonia Moreira e Einat Hauzman, pelos momentos de descontração, alegria e companheirismo, e por todo auxilio prestado.

Ao professor Dr. Ciro Alberto de Oliveira Ribeiro da Universidade Federal do Paraná, pela ajuda e auxilio prestado com as intoxicações e por abrir as portas de seu laboratório, o que foi crucial para realização deste trabalho.

A professora Dra . Sonia Grötzner da Universidade Federal do Paraná, uma pessoa querida e agradável que é apaixonada pelo o que faz e que ganhou meu respeito e admiração quase que instantaneamente, obrigado pela paciência e ajuda prestada durante minhas estadias em Curitiba e pelas contribuições intelectuais e práticas feitas ao trabalho.

A professora Dra . Dânia Emi Hamassaki da Universidade de São Paulo, por permitir o uso de materiais e equipamentos de seu laboratório e a sua aluna Kelly e a sua técnica de laboratório Sayami, por sempre estarem disponíveis e prontas a ajudar.

Ao Professor Dr. Silvio Marques Zanatta da Universidade Federal do Paraná, pelo uso do criostato presente em seu laboratório.

A professora Dr ${ }^{a}$. Silene Maria Araújo de Lima da Universidade Federal do Pará, por ter me recebido de braços abertos em seu laboratório, por ter visto meu trabalho com olhos cuidadosos e por todo ensinamento e ajuda intelectual prestada durante minha estadia em Belém.

A Izabela Pauline de Jesus, uma pequena grande pessoa, companheira e pau pra toda obra durante minas estadias em Curitiba, sua ajuda foi de extrema importância para o sucesso dos experimentos e manutenção dos animais.

Ao aluno de IC Rafael Mantuaneli Ferraro, pela convivência no lab e pela ajuda prestada.

Ao Secretario do laboratório, Claudiel dos Santos pela ajuda nos momentos de sufoco. 
Aos funcionários do Instituto de Psicologia, em especial ao Marcos do setor de veículos e ao Noel do setor de manutenção e serviços gerais do PSE.

A FAPESP, CAPES e PROCAD, pela concessão de bolsa e auxilio financeiro para realização deste trabalho.

Ao Alexandre Gajewski e ao Fábio Higa pela ajuda de extrema importância.

Aos meus amigos, pela amizade e companheirismo. E em especial agradeço a Luciane Babeto, Fábio Carvalho, Paula Bertaia e Lucas Teixeira, por sempre estarem por perto e fazerem parte do meu dia-a-dia.

A minha família, base do meu ser. E em especial aos meus pais que são responsáveis pelo o que eu sou hoje.

E a Deus, que é quem me guia e ilumina o meu caminho. 
"Que os vossos esforços desafiem as impossibilidades, lembrai-vos de que as grandes coisas do homem foram conquistadas do que parecia impossível."

Charles Chaplin 


\section{Índice Geral}

1. Introdução. .01

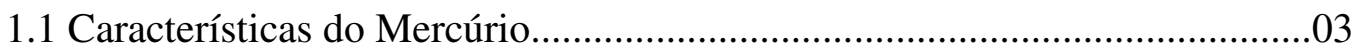

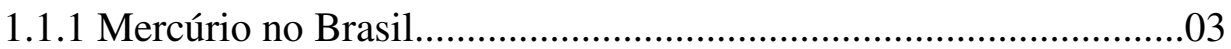

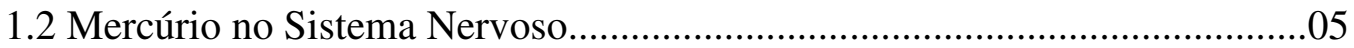

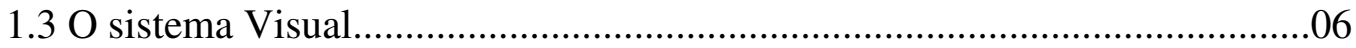

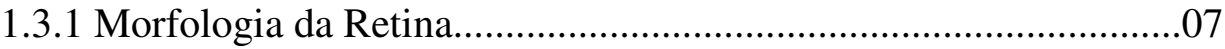

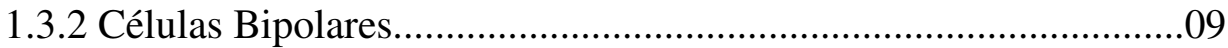

1.3.2.1 Características Morfológicas das Células Bipolares........10

1.3.3 Células Ganglionares................................................................11

1.3.4 O Sistema Visual de Peixes.......................................................12

1.4 Efeitos da Intoxicação Mercurial no Sistema Visual.....................................14

1.4.1 Bioensaios Realizados Para Estudo da Toxicidade ........................15

1.4.1.1 Toxicidade Aguda.......................................................15

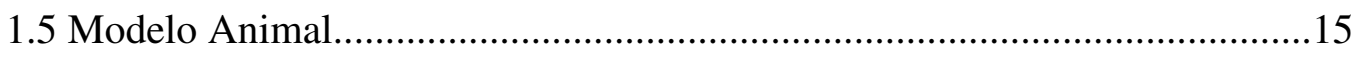

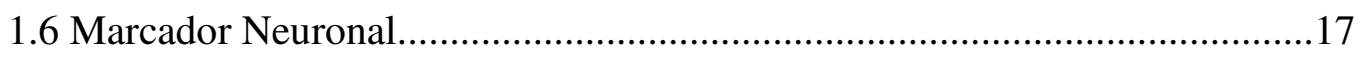

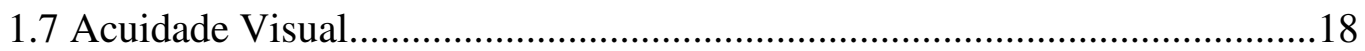

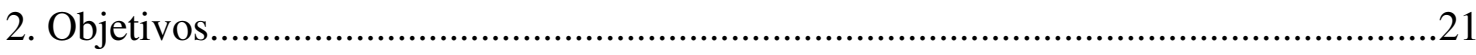

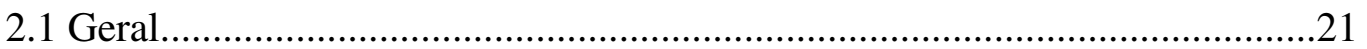

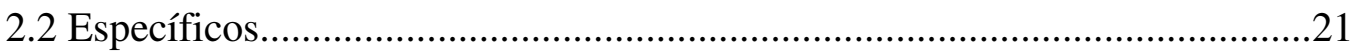

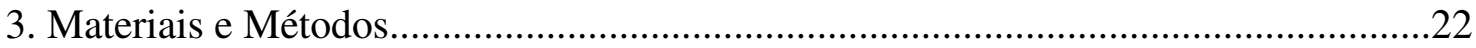

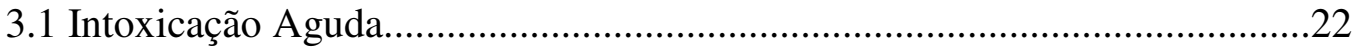

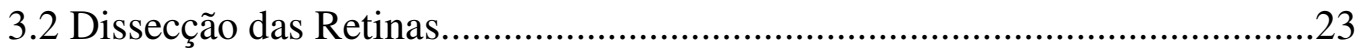

3.3 Imunohistoquímica e Coloração de Nissl...................................................25

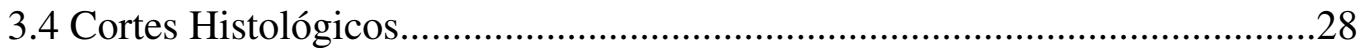

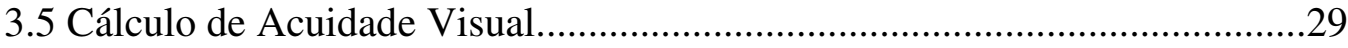




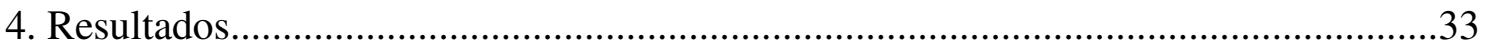

4.1 Distribuição das Células bipolares Imunorreativas a PKC $\alpha$...........................33

4.2 Células Ganglionares Marcadas Pela Técnica de Coloração de Nissl............37

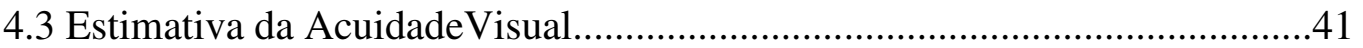

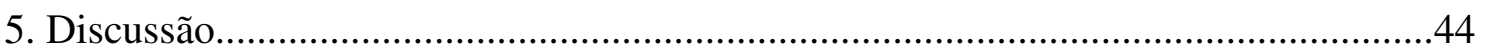

5.1 Efeitos da intoxicação Mercurial em Células da Camada de Células

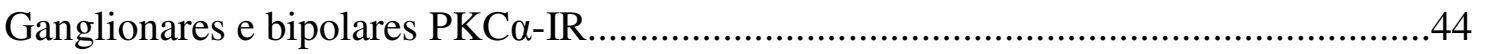

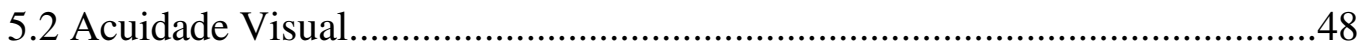

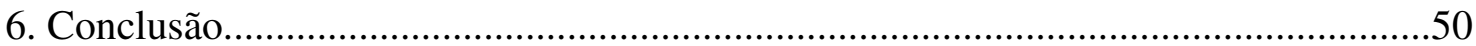

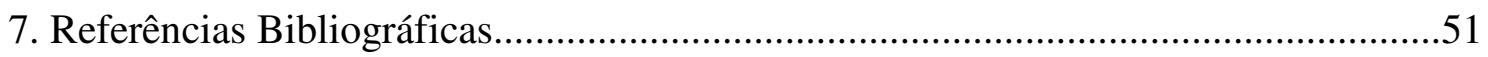

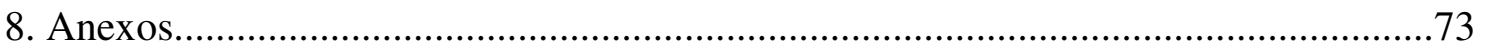




\section{Lista de Figuras}

Figura 01- Representação esquemática do ciclo do mercúrio no ambiente (Imagem:http://verdefato.blogspot.com/2009/04/mercurio-concentracao-oceanoaumento.html)

Figura 02 - Fotomicrográfica de um corte radial da retina de traíra corado com HE, demonstrando as diferentes camadas retinianas. Escala: $10 \mu \mathrm{m}$. (Imagem: Sonia Grötzner) .08

Figura 03- Esquema de células bipolares ON e OFF, segundo sua estratificação 10

Figura 04 - Representação esquemática de um corte transversal de olho humano (A) e de olho de peixe (B). Modificado de Kraaij (2000). .14

Figura 05 - Desenho de um exemplar de Hoplias malabaricus (Imagem: http://www.propesca.com.br/?area=peixes/agua_doce/traira)....

Figura 06 - A freqüência espacial é a medida do número de ciclos formados por grau de ângulo visual. Cada ciclo é formado por uma barra preta e uma branca e a medida é dada em ciclos por grau (cpg). (a) um ciclo por grau; (b) dois ciclos por grau (imagem: http://webvision.med.utah.edu/)

Figura 07 - Foto tirada durante dissecção da retina no laboratório de Histologia da Retina da Professora Sonia Grötzner, do departamento de Biologia Celular da UFPR. Escala $2 \mathrm{~cm}$.

Figura 08 - Retina de um olho esquerdo de Hoplias malabaricus dissecada evidenciando o nervo óptico (NO) e a fissura embrionária (FE). Parâmetros utilizados para a orientação retiniana. Escala: $2 \mathrm{~mm}$. Foto: Sonia Grötzner. 
Figura 09 - (A) representação esquemática do sistema de divisão retina em quadrantes, levando-se em consideração o nervo óptico (NO) e o início da fissura embrionária (FE) (Mofificado de Cameron e Easter, 1993). (B) Representação esquemática da divisão das retinas em centro e periferia (elipses), campos amostrados (pontos vermelhos) e quadrantes retinianos (tangentes cortando o eixo 0, representado pelo nervo óptico). Escala: $2 \mathrm{~mm}$.

Figura 10 - Corte transversal do olho de traíra (Hoplias malabaricus). A linha pontilhada demarca a distância posterior nodal (do cristalino até a retina). A figura A demonstra o máximo que o cristalino invade a pupila (para focar objetos próximos) e a figura B representa a retração do mesmo (para focar objetos mais distantes) (Imagens: Sonia Grötzner)

Figura 11 - Imunohistoquímica para proteína kinase $\mathrm{C}$ alfa em retina de peixe teleósteo, traíra (Hoplias malabaricus). Secção transversal (A) e montagem plana no nível dos corpos celulares (B) e dos pedículos (C). As imagens B e C correspondem a região central da retina. Escala $20 \mu \mathrm{m}$

Figura 12 - Estimativa da densidade média de células bipolares ON em retinas controle e intoxicadas (A): região central (B) e região periférica $(\mathrm{C})$. Resultados obtidos com intoxicação de baixas doses agudas

Figura 13 - Mapas de isodensidade retina controle e intoxicadas, mostrando a distribuição topográfica das células bipolares ON.... .36

Figura 14 - Fotomicrografia das células da CCG do peixe teleósteo traíra (Hoplias malabaricus), coradas com a técnica de Nissl. Região central.. 38

Figura 15 - Estimativa do número total de células ganglionares em retinas controle e intoxicadas (A): região central (B) e região periférica (C). Resultados obtidos com intoxicação de baixas doses agudas. (valor $\mathrm{p}<0,05$, teste $T$-student). 39

Figura 16 - Mapas de isodensidade retina controle e intoxicadas, mostrando a distribuição topográfica de células da CCG. 


\section{Lista de Tabelas}

Tabela 01 - Tamanho, peso e dose de MeHg administrada em cada animal, número de campos amostrados por retina e valores de densidade das células bipolares PKC $\alpha$-IR. Dens. $=$ densidade

Tabela 02 - Tamanho, peso e dose de MeHg administrada em cada animal, número de campos amostrados por retina e valores de densidade das células da CCG coradas com a técnica de Nissl. Dens. $=$ densidade.

Tabela 03 - Valores calculados da Acuidade Visual para cada retina de Traíra Hoplias malabaricus. $\mathrm{DM}=$ densidade media. $\mathrm{PND}=$ distância posterior nodal em mm calculada para cada olho; cpg = resolução espacial em ciclos/grau. 


\section{Resumo}

O presente trabalho tem por objetivo analisar o efeito do metilmercúrio na retina de peixe tropical Hoplias malabaricus (Traíra) através de baixas doses agudas. As intoxicações foram realizadas, por meio de injeção intraperitoneal, nas doses de 0,01 , 0,05, 0,1 e 1,0 $\mu \mathrm{g} / \mathrm{g}$, com um período de quinze dias de depuração do MeHg. Após o término do período de depuração, os olhos foram enucleados e as retinas isoladas foram fixadas em PFA $4 \%$ por 3 horas. As retinas foram conservadas, até o momento do uso (ou por no mínimo 9 horas), em tampão PB $0,1 \mathrm{M}$ a $4^{\circ} \mathrm{C}$. Após os procedimentos imunohistoquímicos para marcação de células bipolares do tipo ON com estratificação na sublâmina b da CPI, as retinas foram aplanadas para confecção de montagens planas para a análise quantitativa de células bipolares $\mathrm{ON}$ imunorreativas a proteína cinase $\mathrm{C} \alpha$. A análise quantitativa das células da camada de células ganglionares (CCG) também foi realizada. Células da CCG foram coradas pela técnica de Nissl, as retinas foram aplanadas em lâminas gelatinizadas e submetidas a uma bateria de desidratação (com diferentes concentrações alcoólicas) e coloração, utilizando cresil violeta como corante. Estas análises foram realizadas em 3 ou 4 retinas para cada dose testada. Análises idênticas foram realizadas nas retinas controle. Todas as retinas foram dividas nos quadrantes dorsal, ventral, nasal, temporal e em centro e periferia. Campos foram fotografados por toda a retina com intervalos de $1 \mathrm{~mm}$, com auxilio do programa Axio Vision por meio de uma câmera digital e um microscópio acoplados a um computador. Os campos amostrados foram contados com o auxilio do programa NIH Scion Imagem 2.0. A densidade média de células foi estimada para cada retina e os grupos intoxicados foram comparados com o grupo controle (Teste T-student). A partir dos dados de densidade celular, mapas de isodensidade foram confeccionados, além de permitir estimar o poder de resolução teórico da acuidade visual de cada um dos animais experimentais utilizados para análise de células da CCG a partir da densidade máxima de células. Evidenciamos que as baixas doses agudas testadas não causam diminuição na densidade célular de células bipolares $\mathrm{ON}$ e células da CCG, comparado ao grupo controle. Não houve reduções significativas na densidade de células para ambos os tipos celulares analizados em nenhuma das regiões retinianas nas doses de $\mathrm{MeHg}$ testadas. Assim, a intoxicação de $\mathrm{MeHg}$ por baixas doses agudas não alterou o poder de resolução teorio da acuiade visual dos animais testados. 


\begin{abstract}
This study aims to examine the effects of low acute doses of methylmercury $(\mathrm{MeHg})$ on the retina of the tropical fish Hoplias malabaricus (Thraira). Four levels of $\mathrm{MeHg}$ intoxication were induced by intraperitoneal injection of doses of either $0.01,0.05,0.1$ or $1.0 \mu \mathrm{g} \mathrm{MeHg} / \mathrm{g}$ of body weight, followed by a fifteen day period of depuration of MeHg. After the depuration period, the eyes were harvested, and the retinas were isolated and fixed in $4 \%$ paraformaldehyde for 3 hours. The retinas were then stored (for at least for 9 hours) in $0.1 \mathrm{M}$ sodium phosphate $\mathrm{PB}$ buffer at $4^{\circ} \mathrm{C}$ until the time of analysis. ON bipolar cells in sublamina $b$ of the inner plexiform layer immunoreactive to protein Kinase $\mathrm{C} \alpha$ were immunohistochemically labeled, and the retinas were flattened to make whole mounts for quantitative analysis of ON bipolar cell densities. Quantitative analysis of cells in the retinal ganglion cell layer (GCL) was also performed. GCL cells were Nissl stained, and the retinas were flattened on gelatinized slides and subjected to another battery of dehydration (with different alcohol concentrations) and staining using cresyl violet. These analyses were carried out in 3 or 4 retinas for each dose tested. Identical analyses were performed on the control retinas. All retinas were divided into regions: dorsal, ventral, nasal, temporal, center and periphery. Sample retinal fields were photographed throughout the retina at intervals of $1 \mathrm{~mm}$, with a digital camera attached to a microscope using Axio Vision software coupled to a computer. ON bipolar and GCL cells within the fields were counted with the help of the NIH Scion Image 2.0 software. The average density $\left(\mathrm{mm}^{2}\right)$ of both types of cells was estimated for each retina and the data from each of the four $\mathrm{MeHg}$ intoxicated groups were compared with the control group values (Student t-test). From the density data we derived isodensity maps, permitting us to estimate the theoretical resolving power (maximum visual acuity) of each of the experimental animals used from the maximum density of cells in the ganglion cell layer. We showed that low acute doses of $\mathrm{MeHg} / \mathrm{g}$ do not decrease cell densities of either ON bipolar cells or cells in the GCL, compared to controls. There were no significant decreases in cell density (counts) for either cell type in any of the retinal regions, for any of the $\mathrm{MeHg}$ doses tested. Thus, acute low-dose $\mathrm{MeHg}$ intoxication did not degrade the estimates of the animals' theoretical resolving power.
\end{abstract}




\section{Introdução}

O grande avanço tecnológico e a globalização são refletidos também no uso desenfreado dos recursos naturais, produção e descarte de lixo e resíduos tóxicos, os quais não recebem tratamento adequado, tendo como destino final o meio ambiente, causando graves problemas aos seres vivos devido à contaminação dos recursos naturais.

Os metais pesados fazem parte destes resíduos tóxicos e são amplamente utilizados em grande escala na atualidade, em diversas atividades (industriais, agrícolas e manufatureiras). A falta de controle e cuidados no uso de tais materiais e a falta de estudos sobre os mesmos, coloca em risco a saúde de populações que são afetadas pela intoxicação com metais pesados (Vimercati et al., 2001; Castoldi et al., 2003; Kingman et al., 2005).

Tais produtos são bioacumuladores e causam grande impacto ecológico por sua incorporação nos tecidos vivos e assimilação na cadeia alimentar (Oga et al., 1996).

Recursos hídricos estão amplamente expostos à contaminação por metais pesados e diversos agentes químicos de alta toxicidade, que poluem e prejudicam o ambiente. O grande aumento da industrialização, a intensa atividade agrícola e a concentração cada vez mais próxima das atividades humanas dos recursos hídricos, têm causado um descarte descontrolado de resíduos tóxicos nos ambientes aquáticos. Os metais pesados estão entre as substâncias químicas mais estudadas presente nos ambientes aquáticos, devido à sua capacidade cumulativa e persistência no ambiente (Kehring et al., 2002).

Desde o início da Revolução Industrial, o metilmercúrio (MeHg) vem apresentando um aumento considerável nos níveis ambientais e hoje está presente por 
todo o globo terrestre em níveis que afetam a vida dos seres vivos (Boening, 2002). Após a incorporação do $\mathrm{MeHg}$ na cadeia alimentar, independente da forma de sua emissão, o consumidor final é sempre o ser-humano, através do consumo de animais intoxicados (pescado em sua grande maioria) (Fig. 01).

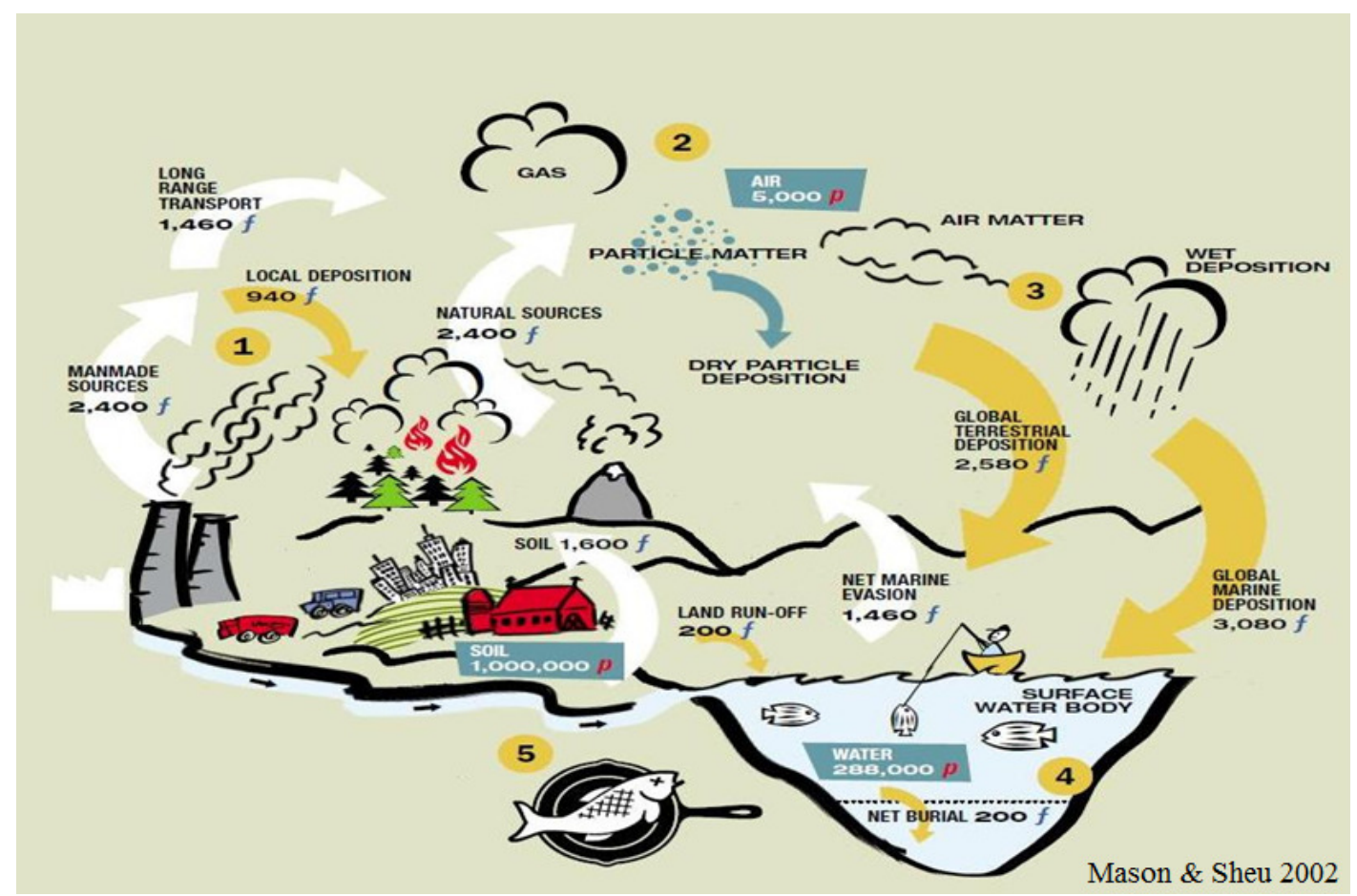

Figura 01- Representação esquemática do ciclo do mercúrio no ambiente (Imagem:http://verdefato.blogspot.com/2009/04/mercurio-concentracao-oceano-aumento.html).

Ocorreram na historia alguns casos de contaminação por Mercúrio (Hg) e seus compostos, o maior e o mais famoso, que ficou conhecido mundialmente como a doença de Minamata, ocorreu na Baía de Minamata no Japão em 1953. O desastre foi ocasionado por uma das maiores empresas do Japão, a Chisso Fertitilizer Co. Ltd., que produzia fertilizantes químicos, resinas sintéticas, plásticos e compostos químicos. O MeHg era produzido como subproduto do processo de produção da acetaldeído e os resíduos eram então lançados na Baía de Minamata, de onde provinha o pescado que alimentava a população de Minamata. Outro exemplo terrível ocorreu em 1997, na 
Universidade de Dartmouth, onde fatalmente a pesquisadora americana Karen Wetterhahn morreu meses após ter sido contaminada por uma ou duas gotas de dimetilmercúrio puro, durante a manipulação do composto em um experimento. No ano de 1970, no Iraque, Paquistão, Gana e Guatemala ocorreram casos de contaminação de agricultores e seus familiares, que utilizavam grãos tratados com fungicidas à base de metil e etilmercúrio na confecção de pão caseiro. No caso Iraque, mais de 6.900 pessoas foram hospitalizadas e pelo menos 459 vieram a óbito devido à intoxicação. Em 1969, nos Estados Unidos, pessoas se intoxicaram por consumir carne suína de porcos que eram alimentados com grãos tratados com fungicidas que continham organomercuriais (Bisinoti \& Jardim, 2004).

\subsection{Características do Mercúrio}

O mercúrio ocorre naturalmente no ambiente sob a forma elementar, orgânica e inorgânica. É um elemento constituinte da terra e um metal pesado. Em estado líquido possui uma coloração prata (Seiler \& Sigel, 1988).

O mercúrio não pode ser quebrado ou degradado em substâncias inofensivas. Em sua forma elementar é inofensivo para os animais e o ambiente, porém, quando em circulação na biosfera não é degradado ao longo do tempo. Os diversos fatores ambientais (bióticos e abióticos) contribuem para sua transformação em outros compostos mercuriais, mantendo o metal no ciclo entre o ar, a terra, a água e os organismos. As diferentes formas mercuriais apresentam comportamentos distintos entre si no ambiente e quando absorvidos pelos organismos apresentam alta toxicidade.

\subsubsection{Mercúrio no Brasil}

A partir da década de 1940 o Brasil recebeu grande quantidade de mercúrio devido à mineração do ouro, nas regiões amazônicas do Rio Negro e de Serra 
Pelada (WHO, 1990). Nas décadas de 1970 a 1995, foram liberados na Amazônia brasileira cerca de 1.500 a 3.000 toneladas de mercúrio, grande parte através das atividades do garimpo (Brabo et al., 2000).

O mercúrio é utilizado para extração de ouro das rochas em temperatura ambiente, formando uma liga, a amálgama. O ouro é purificado através do aquecimento desta liga, liberando o vapor de mercúrio durante o aquecimento e durante os processos de lavagem, e este metal é então descartado nos leitos dos rios, onde passa a ser incorporado à cadeia alimentar. Devido à bioacumulação, os peixes situados nas porções mais altas da cadeia trófica, principalmente aqueles consumidos pela população, são um elo importante entre a poluição dos recursos hídricos pelo mercúrio e a saúde humana (Brabo et al., 2000).

A erosão dos solos que ocorre em conseqüência do desmatamento realizado pela população local em função do desenvolvimento da agricultura, representa outra importante fonte de contaminação mercurial na Amazônia, pois acarreta a liberação do mercúrio contido naturalmente no solo, tal liberação é estimada em 500 a $3000 \mu \mathrm{g}$ $\mathrm{Hg} / \mathrm{m}^{3}$ por centímetro de solo erodido (Roulet et al., 1998).

Grupos de pesquisa investigam a contaminação mercurial por meio de análise e monitoramento das concentrações de mercúrio nas águas, sedimentos e animais, principalmente peixes, em regiões afetadas por atividades mineradoras.

A contaminação pode se dar de duas formas, podendo ser ocupacional ou alimentar. A contaminação ocupacional ocorre em decorrência da atividade garimpeira. O mercúrio é utilizado no processo de amalgação do ouro, a amalgama é então purificada, através do aquecimento e lavagem da mesma, causando liberação de mercúrio na atmosfera e nos rios. A contaminação alimentar ocorre através do consumo 
de pescado contaminado, configurando uma importante fonte de exposição ao mercúrio para humanos, tornando os peixes um importante elo de estudo na contaminação por metais pesados.

\subsection{Mercúrio no Sistema Nervoso}

O sistema nervoso, em especial o sistema visual (parte constituinte do sistema nervoso central (SNC) é fortemente afetado pela intoxicação mercurial (WHO, 1990; Merigan, 1979; Merigan et al., 1983; Castoldi et al., 2003). Estudos mostram que o mercúrio afeta principalmente o cerebelo (Igata, 1993; Castoldi et al., 2003; Fonnum \& Lock, 2000; Warfvinge, 2000) e o sistema visual (Merigan 1979; Merigan et al., 1983; Castoldi et al., 2003; Mela et al., 2010; Tanan et al., 2006; Bonci et al., 2006; Barboni et al., 2008, 2009; Costa et al., 2008 a, b; Feitosa-Santana et al., 2007, 2008; Ventura et al., 2004, 2005; Canto-Pereira et al., 2005) além de efeitos neuropsicológicos (Zachi et al., 2008; Taub et al., 2006; Barboni et al., 2009).

O metilmercúrio $(\mathrm{MeHg})$ em especifico, tem predileção pelo $\mathrm{SNC}$, em todas as espécies estudadas, inclusive no homem (Carta et al., 2003). Outros estudos realizados com seres humanos expostos ao $\mathrm{MeHg}$, evidenciaram que perdas visuais são uma característica constante presente na intoxicação por este composto mercurial (Kjellstrom et al., 1989; Grandjean, 1999; Sakamoto et al., 2000), o que também foi demonstrado em primatas não humanos, gatos e ratos (Helberg \& Hystrom 1972; Merigan 1980) assim como danos morfológicos no cérebro e na retina de ratos (Slotkin et al. 1985) e na retina do peixe tropical Hoplias malabaricus (Bonci et al., 2006; Prodocimo, 2009).

Os mecanismos fisiológicos que causam alterações visuais como comprometimento do campo visual periférico, disfunção da visão central, perda da sensibilidade ao contraste e perda da discriminação de cores ainda não foram totalmente 
esclarecidos (WHO, 1990; Merigan, 1979; Merigan et al., 1983; Castoldi et al., 2003; Barboni et al., 2008, 2009; Costa et al., 2008a, b; Feitosa-Santana et al., 2007,2008; Ventura et al., 2004, 2005; Canto-Pereira et al., 2005).

O limite seguro para o uso do mercúrio ainda é um enigma, uma vez que as consequiências causadas pela contaminação por baixas dosagens ainda são questionáveis; aliado a isso, a grande difusão e utilização de compostos mercuriais ainda nos dias atuais, caracterizam a intoxicação mercurial como um problema de saúde pública de alta gravidade e periculosidade, por afetar principalmente o sistema nervoso central.

\subsection{O Sistema Visual}

O sistema visual é formado por vias especializadas cuja atividade se origina em neurônios da retina responsáveis pela transdução da luz em resposta neural. Parte do processamento visual inicia-se na retina, onde estão presentes mecanismos neurais para percepção do contraste de brilho, visão de cores e de movimento (Bear et al., 2002; Kandel et al., 2003; Lent,2001).

Os olhos são complexos órgãos do sentido formados por três camadas esféricas concêntricas. A parte externa ou fibrosa compreende a córnea e esclera. A camada intermediaria compreende a coróide, corpo ciliar e íris e a camada interna ou sensorial compreende a retina. Cada olho tem uma camada de receptores, um sistema de lentes para focalizar uma imagem nesses receptores e um sistema de neurônios para processar os sinais provenientes dos fotorreceptores e transmitir potenciais de ação para o cérebro (Bear et al., 2002; Cunningham, 1993; Kandel et al., 2003; Lent,2001; Mello, 2001).

O funcionamento do sistema visual ocorre por meio de mecanismos que variam entre os diferentes grupos e espécies, os quais apresentam alta conservação de 
características morfológicas e fisiológicas, ao longo da evolução. Tais particularidades e seu funcionamento estão intimamente ligados ao habitat e comportamento de cada animal (Líber \& Oliveira, 2005)

\subsubsection{Morfologia da retina}

A estrutura da retina foi descrita há mais de um século por Santiago Ramon y Cajal (1893). Seus trabalhos conduziram a importantes conclusões sobre os princípios básicos da organização do sistema nervoso (Piccolino, 1988).

A retina (fig.02), camada mais interna do olho, onde são captados os estímulos visuais é parte integrante do sistema nervoso central (SNC), e contém cinco tipos principais de neurônios que se comunicam por meio de um intricado padrão de conexões, mas com um arranjo anatômico em camadas (Cajal, 1893).

A retina está dividida em 10 camadas: (1) epitélio pigmentado, (2) camada de fotorreceptores cones e bastonetes (segmentos externos e internos), (3) membrana limitante externa (MLE), (4) camada nuclear externa (CNE), com os núcleos dos fotorreceptores, (5) camada plexiforme externa (CPE), contendo as sinapses das células bipolares e horizontais com os fotorreceptores, (6) camada nuclear interna (CNI) dos corpos celulares das células bipolares, horizontais e amácrinas, (7) camada plexiforme interna (CPI), contendo as conexões das células ganglionares com as células bipolares e amácrinas, (8) camada de células ganglionares (CCG), (9) camada de fibras nervosas, contendo os axônios das células ganglionares, passando para o nervo óptico, (10) membrana limitante externa. 


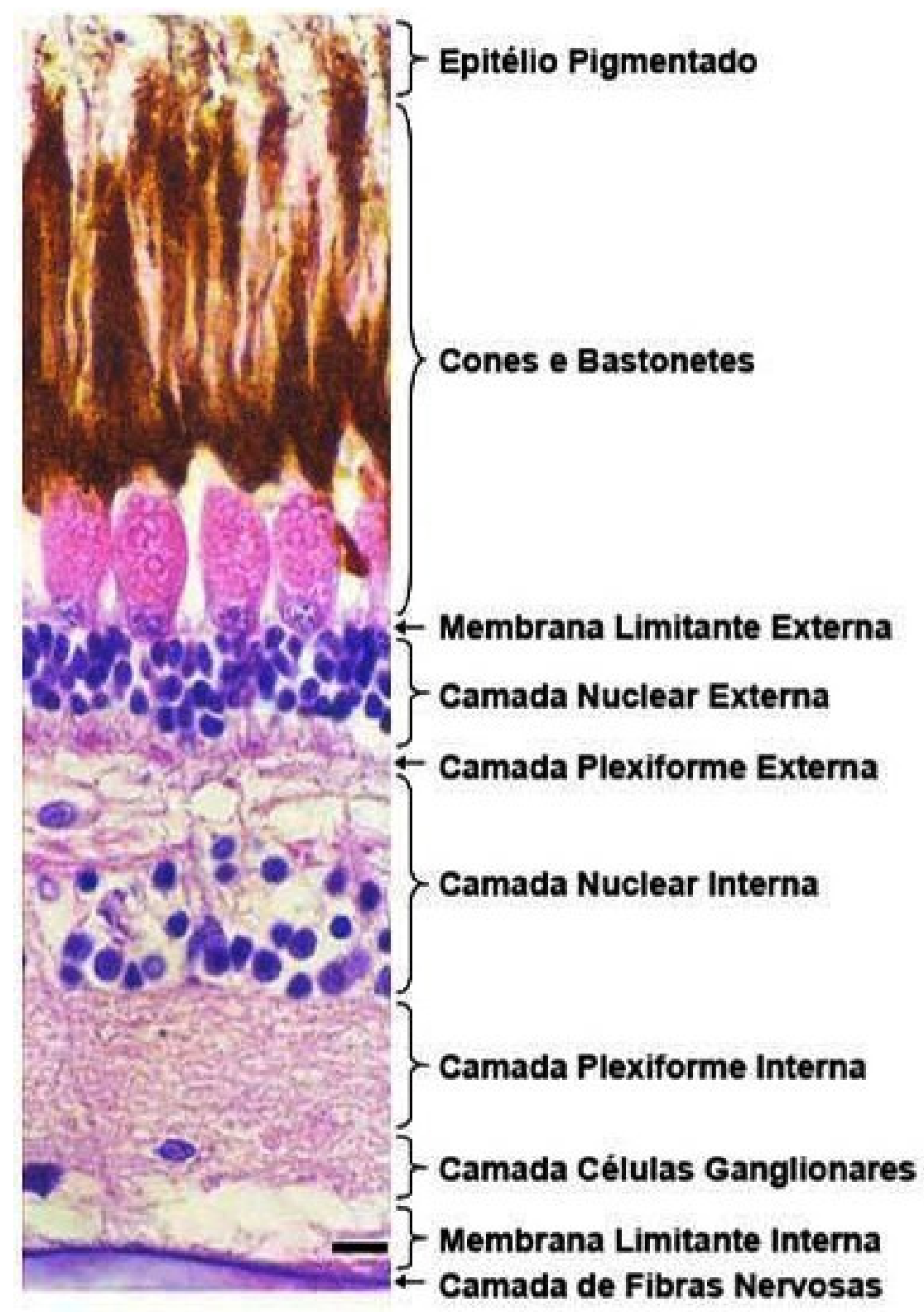

Figura 02 - Fotomicrográfica de um corte radial da retina de traíra corado com HE, demonstrando as diferentes camadas retinianas. Escala: $10 \mu \mathrm{m}$. (Imagem: Sonia Grötzner).

Os cinco tipos principais de células nervosas na retina organizam-se em estágios sucessivos: neurônios de primeira ordem (fotorreceptores), que fazem a transdução da luz em sinal neural, enviando potenciais para os de segunda ordem (horizontais e bipolares), os quais por sua vez se comunicam com os de terceira ordem (amácrinas e ganglionares). 


\subsubsection{Células Bipolares}

As células bipolares (CB) são neurônios de $2^{\circ}$ ordem que se comunicam com fotorreceptores e células horizontais na CPE e com células ganglionares e amácrinas, na CPI (Kaneko, 1970).

A resposta elétrica das CBs à luz pode ser de dois tipos: despolarizando ou hiperpolarizando por efeito da estimulação luminosa. O tipo de resposta depende do tipo de contato sináptico com os fotorreceptores. Contatos invaginantes estão relacionados a uma resposta despolarizante à luz (CB tipo $\mathrm{ON})$, enquanto células com contatos via junção basal tem respostas hiperpolarizantes (CB tipo OFF) (fig. 03).

Na CPI, o tamanho e a localização dos terminais axonais das CB refletem a sua funcionalidade na organização desta camada em sub-lâminas as quais estão presentes na retina de todos vertebrados. Esta organização foi descrita primeiramente por Santiago Ramón y Cajal, que mostrou que a CPI pode ser dividida funcionalmente em duas sublâminas: a e b. A sub-lâmina a compõe os estratos 1 e 2 de Ramón y Cajal (1893), nos quais CB OFF estabelecem conexão com células ganglionares (CG) OFF. A sub-lâmina b inclui o estrato 3 (há espécies que apresentam mais de 3, os estratos de 3 a 5) onde encontram se os terminais axonais das $\mathrm{CB}$ ON, que estabelecem sinapses com CG ON (Kolb et al., 2001). Tomando como exemplo a retina de gato (fig. 03). 


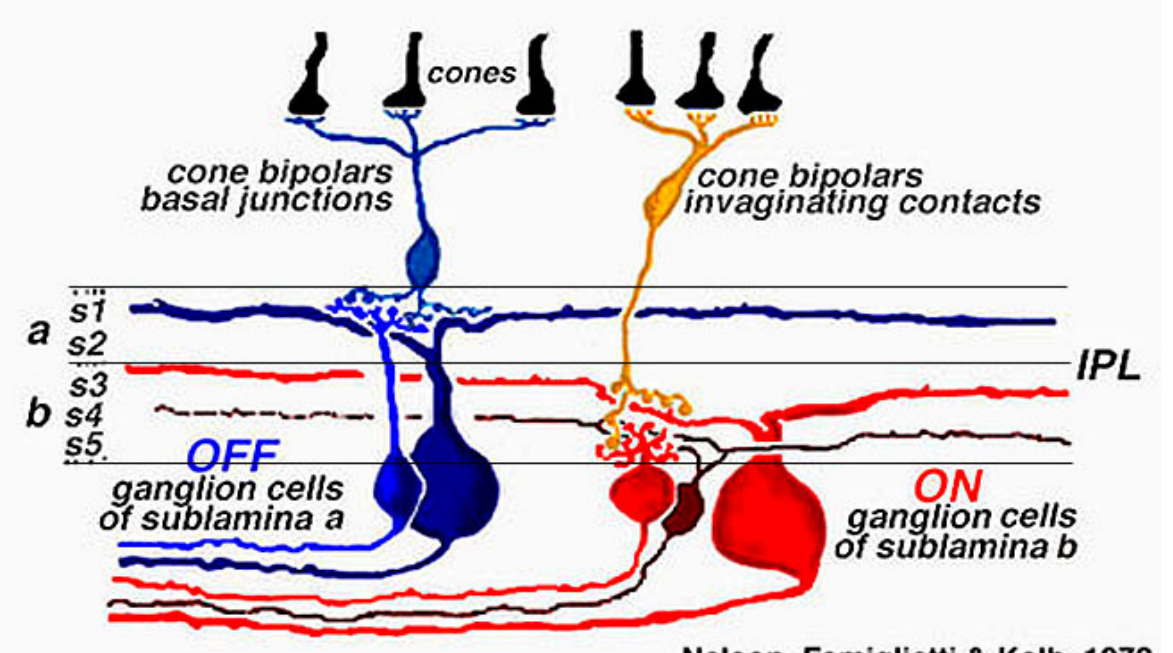

Nelson, Famiglietti \& Kolb, 1978

Figura 03- Esquema de células bipolares ON e OFF, segundo sua estratificação.

\subsubsection{Características morfológicas das células bipolares}

A proteína cinase $\mathrm{C}$ do subtipo alfa $(\mathrm{PKC} \alpha)$ está presente em $\mathrm{CB}$ do tipo $\mathrm{ON}$ (Werblin \& Dowling, 1969; Kaneko, 1970; Caminos et al., 2000; Shimbo et al., 2000). Tal proteína é expressa por diferentes tipos celulares, na retina por exemplo, é expressa pelas demais células, porém as células bipolares expressam um quantidade maior de PKC (Girard et al., 198; Saito et al., 1988; Wood et al., 1986), e está presente em grande quantidade no SNC (Kikkawa et al., 1982; Minakuchi et al., 1981), atuando na fosforilação de outras proteínas. As diferentes isoenzimas de PKC foram classificadas em subespécies do tipo alfa, beta 1, beta 2, gama, teta entre outras; sua localização em diferentes espécies e tipos celulares podem ser vistas na revisão de Wood et al. (1997).

Em retina de vertebrados, subtipos diferentes de PKC são expressos por diferentes tipos celulares, o que varia de acordo com o animal. Na retina de peixes foi encontrada a proteína cinase $\mathrm{C}$ do subtipo alfa $(\mathrm{PKC} \alpha)$ em células bipolares do tipo ON, comumente encontrada também em retina de tartarugas, ratos e coelhos (Suzuki \& Kaneko, 1990; Cuenca et al., 1990; Osborne et al., 1992). Na literatura, CB do tipo ON 
estão descritas como participantes da via de processamento da informação dos bastonetes (Job \& Lagnado, 1998). Nos peixes, as células bipolares do tipo ON que expressam $\mathrm{PKC} \alpha$ recebem aferências tanto de bastonetes quanto de cones, células bipolares mistas (Kaneko, 1970; Shimbo et al., 2000). Sua morfologia é caracterizada pela presença de um pedículo em forma de bulbo. Além do aspecto morfológico é parte de sua caracterização o fato de tais células estarem estratificadas na sublâmina $\mathrm{ON}$ da CPI, na sublâmina $\mathbf{b}$ (estrato 3) o que também foi evidenciado em retina de traíra pelo presente trabalho e por Bonci (2006).

\subsubsection{Células Ganglionares}

As células ganglionares (CG) são neurônios de terceira ordem encontrados na CCG, que é constituída pelos núcleos das CG e algumas espécies podem apresentar nessa camada células amácrinas e horizontais deslocadas.

As CG são as últimas células da retina a receber e processar a informação luminosa captada pelos fotorreceptores. Este é o único ponto de saída da informação visual, através de potenciais de ação que são levados via nervo óptico para áreas centrais do SNC (Ali \& Klyne, 1985). Um tipo de célula ganglionar descoberto recentemente, possui melanopsina, um pigmento fotossensível que responde diretamente à luz. Compondo uma via retino-hipotalâmica (em mamíferos camundongo), que informa aos núcleos supraquiasmáticos a alternância claro-escuro, participando do ciclo circadiano (Rollag et al., 2003).

As células ganglionares foram primeiramente descritas por Ramón y Cajal (1893), através da técnica de Golgi em retina de vertebrados. Ramón y Cajal classificou a diversidade de CG, através da morfologia dendritica, extensão do corpo celular e 
tamanho da árvore dendrítica, assim como o número de sublâminas da CPI onde estas células se ramificam.

Dentre os diferentes tipos de CG, distinguem-se células que dão origem a duas vias visuais, denominadas magno e parvocelular (tal classificação é utilizada para primatas). Células ganglionares grandes, que possuem um campo receptivo maior são consideradas magnocelulares, enquanto, ganglionares menores, que possuem um campo receptivo menor são consideradas parvocelulares. As células pertencentes à via magno ligam-se com várias células bipolares, possuindo um campo receptivo grande, o que lhes confere baixa resolução. Atuam na sensibilidade ao contraste de luminância em baixas freqüências espaciais e na visão noturna, possuem rápida condutividade e sensibilidade a movimentos rápidos além de uma alta resolução temporal. As células pertencentes à via parvo ligam-se a uma célula bipolar, possuindo um campo receptivo pequeno, o que lhes confere alta resolução espacial, atuam na visão de cores, possuem condutividade lenta e sensibilidade a movimentos lentos (Tootell et al., 1988; Kaplan \& Shapley, 1986). Assim como as CB, as CG possuem um arranjo em centro e periferia, que reflete o arranjo dos seus dendritos nas sublâminas ON e OFF da CPI. Desta forma, as CG respondem antagonicamente a estímulos luminosos, como foi estudado em gatos (Famigliettti \& Kolb, 1976; Nelson et al., 1978; Boycott \& Wassle 1974; Nelson et al., 1993).

\subsubsection{O sistema Visual de Peixes}

O desenvolvimento visual dos peixes foi influenciado de forma significativa pelas características do ambiente em que vivem (Lythgoe, 1991). Um desses fatores são as propriedades físicas do ambiente aquático que limitam a penetração da luz na coluna de água. Considerando-se um ambiente de água pura, a água torna-se progressivamente 
azulada com o aumento da profundidade, pelo fato de os comprimentos de ondas longos serem barrados próximo à superfície, constituindo assim ambientes com diferentes cromaticidades em função da profundidade (Hawryshyn, 1997). A existência de diferentes ambientes cromáticos favorece o desenvolvimento de mecanismos adaptados para a percepção e processamento da luz disponível no ambiente, pelo sistema visual das espécies que vivem nesses ambientes (Bowmaker, 1991).

Ao longo da evolução os pigmentos visuais foram selecionados entre as diversas espécies de peixes adaptando-se aos diferentes ambientes (Levine \& MacNichol, 1979; Hawryshyn, 1997; Reckel et al., 2002; Hart et al., 2004; Pointer et al., 2005; Parry et al., 2005).

O olho de um peixe teleósteo (fig. 04) é adaptado à visão aquática.e possui um índice de refração diferente da do ar. O índice de refração do ar é 1,0003 e da água, 1,33, aproximadamente o mesmo da córnea humana. Nos peixes, o índice de refração é o mais alto dentre os diferentes animais, o cristalino é extremamente convexo, atingindo a forma esférica. Os teleósteos possuem um olho com córnea plana, cristalino esférico e bastante saliente para obter um poder de refração maior (1.65), devido ao índice de refração da água (Kraaij, 2000). Mas possui grande semelhança com os olhos da maioria dos vertebrados variando de tamanho, posição e estrutura. Tais variações são devidas ao grande número de espécies e a estratégias adaptativas (Takashima \& Hibiya, 1998).

A retina dos peixes possui CB que podem receber aferências apenas de cones ou uma mistura de cones e bastonetes, conhecidas como $\mathrm{CB}$ mistas, descritas primeiramente por Ramón y Cajal, em 1893 e posteriormente estudadas por outros autores (Sherry \& Yazylla, 1993; Tachibana, 1999; Joselevitch, 2005). 
A

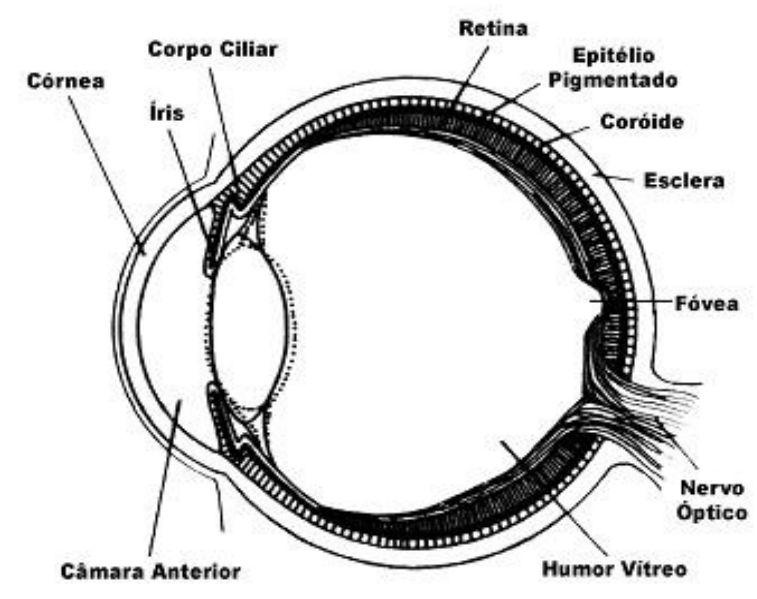

B

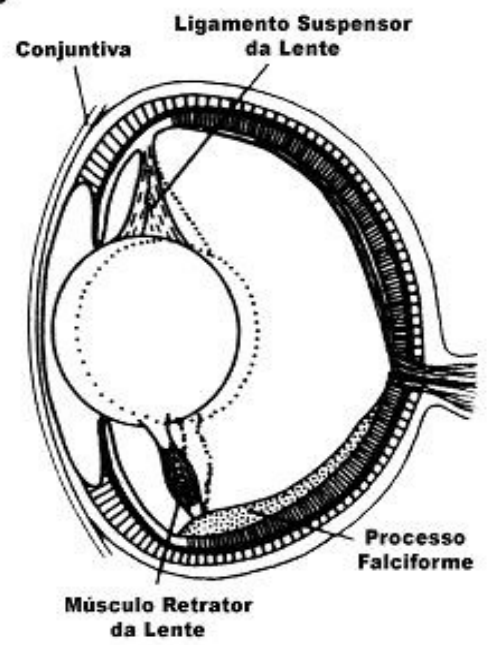

Figura 04 - Representação esquemática de um corte transversal de olho humano (A) e de olho de peixe (B). Modificado de Kraaij (2000).

\subsection{Efeitos da Intoxicação Mercurial no Sistema Visual}

A avaliação das funções visuais após administração de mercúrio foi estudada em modelos animais como peixes (Hawryshyn \& Mackay, 1979; Hawryshyn et al., 1982; Lima et al., 2003; Tanan et al., 2006; Bonci et al., 2006) anfíbios (Tessies-Lavigne et al., 1985) e mamíferos como gatos (Gitter et al., 1988) e primatas não humanos (Warfvinge \& Bruun, 1996, 2000; Rice \& Gilbert, 1992; Burbacher et al., 2005).

Em seres humanos, existem vários relatos sobre os efeitos tóxicos da exposição mercurial nas funções visuais (Cavalleri et al., 1995; Cavarelli \& Gobba, 1998; Lebel et al., 1996, 1998; Damin, 2000; Silveira et al., 2003, 2004; Urban et al., 2003; Ventura et al., 2004, 2005; Canto-Pereira et al., 2003, 2005; Ventura et al., 2003a, 2003b, 2003c; Simões, 2004; Lago, 2005; Feitosa-Santana, 2006). Estudos sobre os efeitos do metilmercúrio mostraram comprometimento severo do campo visual periférico (Igata, 1993), bem como disfunções da visão central, com perda da sensibilidade ao contraste 
acromático para modulação espacial e temporal (Lebel et al., 1996, 1998; Ventura et al., 2004, 2005; Canto-Pereira et al., 2005; Lago, 2005) e perdas na discriminação de cores (Cavarelli et al., 1995; Cavarelli \& Gobba, 1998; Ventura et al., 2004, 2005; FeitosaSantana, 2006; Simões, 2004; Urban et al., 2003; Ventura et al., 2003a, 2003b; 2003c; Damin, 2000; Silveira et al., 2003).

\subsubsection{Bioensaios Realizados para Estudo de Toxicidade}

Os danos causados a um tecido por um metal como o mercúrio, podem ser estudados através de bioensaios, em experimentos que simulam a intoxicação variando dose e tempo de exposição, e que podem ser experimentos de tipo agudo, subcrônico ou crônico dependendo do cronograma de administração da substância tóxica em estudo (Oga et al., 1996).

\subsubsection{Toxicidade Aguda}

Toxicidade aguda refere-se aos efeitos adversos que ocorrem dentro de um curto período, de no máximo duas semanas após administração de uma única dose ou múltiplas, administradas dentro de 24 horas. Através dos resultados obtidos, pode-se caracterizar a relação dose/resposta, para conhecer o mecanismo de ação da substância, identificando possíveis órgãos ou sistemas sensíveis e determinar se há possibilidade de reversão dos efeitos (Oga et al., 1996).

\subsection{Modelo Animal}

Os peixes constituem um grupo de grande importância nas avaliações toxicológicas por estarem presentes em diversos ambientes e apresentarem ampla distribuição geográfica, fazendo parte de diferentes níveis tróficos da cadeia alimentar. 
A espécie escolhida neste trabalho, à traíra Hoplias malabaricus, (fig.05) é um teleósteo tropical da classe Actinopterygii, ordem Characiformes, família Erythrinidae, gênero Hoplias (Bloch, 1794). Esta espécie vive preferencialmente em locais de pouca profundidade, com vegetação aquática abundante, de águas calmas como açudes e lagoas, e apresenta hábitos noturnos (Magalhães, 1931). A escolha da espécie baseouse principalmente na sua posição trófica em relação à cadeia alimentar, o que reflete os efeitos de bioacumulação e biomagnificação do mercúrio e também pelo fato de estar sendo intensamente estudada no Brasil pelo grupo de Oliveira-Ribeiro e colaboradores (2006).

Estudos de toxicologia com traíra realizados por Oliveira-Ribeiro e cols., examinaram os efeitos do metilmercúrio na histologia de órgãos como fígado, rim, brânquias e no metabolismo (Bussolaro et al., 2010; Filipakneto et al., 2008; Mela 2004, 2007; Oliveira-Ribeiro et al., 2006, 2008;).

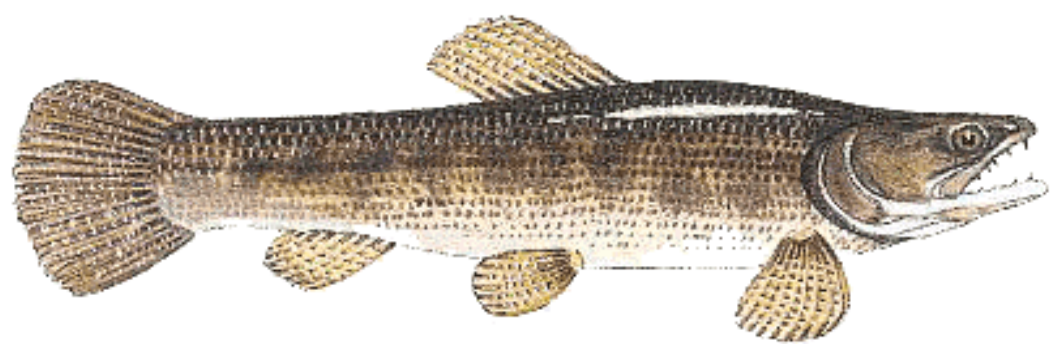

Figura 05 - Desenho de um exemplar de Hoplias malabaricus (Imagem: http://www.propesca.com.br/?area=peixes/agua_doce/traira).

Uma avaliação funcional do sistema visual da traíra também foi realizada em retinas de peixes intoxicados de forma aguda e subcrônica, em estudos eletrofisiológicos (Tanan et al., 2006) e morfológicos (Bonci et al., 2006. Mela, 2009) mostrando a 
viabilidade de utilização desse animal como modelo em bioensaios de intoxicação por metais pesados, para avaliar os efeitos destas substâncias neurotóxicas na retina.

Contudo, apesar desse animal possuir uma ampla distribuição geográfica pela América do Sul, sua obtenção é difícil por não possuir valor comercial e ser visto como uma praga pelos piscicultores.

\subsection{Marcador Neuronal}

O trabalho de Bonci et al. (2006) utilizou a proteína cinase $\mathrm{C} \alpha(\mathrm{PKC} \alpha)$ como marcador neuronal de células bipolares na retina da traíra. Formada por isoenzimas, a PKC $\alpha$ atua sobre os aminoácidos serina e treonina, que compõem diversas proteínas. Está presente em altas concentrações no tecido nervoso, onde exerce importante papel na sinalização neuronal, influenciando a liberação de neurotransmissores, modulando canais iônicos e alterando a função receptora (Tanaka \& Nishizuka, 1994).

A enzima PKC $\alpha$ foi encontrada em células bipolares na retina de diferentes vertebrados (Caminos et al., 2000), como salamandra (Umino et al., 2003), tartaruga (Zhang et al., 1992), galinha (Caminos et al., 1999), bovinos (Shin et al., 2006), ratos (Negishi et al., 1988; Greferath et al., 1990; Osborne et al., 1991,1992; Zhang \& Yeh, 1991; Kosaka et al., 1998; Gabriel et al., 2001), gato (Fykkolodziej et al., 2002), coelho (Usuda et al., 1991; Osborne et al., 1991, 1992; Koistinanho \& Sagar, 1994), macaco (Grünert \& Martin, 1991; Fukuda et al., 1994; Haverkamp et al., 2003), em retina humana (Kolb et al., 1993; Haverkamp et al., 2003) e inclusive na retina de peixes (Suzuki \& Kaneko, 1990; Osborne et al., 1992; Vaquero et al, 1997; Job \& Lagnado, 1998).

O presente trabalho é embasado no estudo de Bonci (2006), em que foram analisadas células amácrinas e bipolares da retina de traíras intoxicadas por mercúrio. 
Em células bipolares, Bonci et al. (2006) analisaram doses altas agudas na situação de intoxicação aguda por injeção intraperitoneal $(2$ e $6 \mu \mathrm{g})$ e mostraram perdas celulares com ambas as doses. Entretanto não são conhecidos os efeitos de doses mais baixas na intoxicação aguda nas células bipolares. A proposta deste trabalho é analisar baixas doses agudas de metilmercúrio, dando continuidade aos trabalhos sobre intoxicação mercurial que vem sendo realizados no Laboratório de Psicofisiologia Sensorial, do Instituto de Psicologia da Universidade de São Paulo. Também serão analisadas as células ganglionares, para que seja possível uma estimativa dos efeitos da intoxicação nesse outro nível da retina, cuja densidade é determinante para a estimativa da acuidade visual, como será descrito a seguir.

\subsection{Acuidade Visual}

A acuidade visual (AV) é a capacidade de resolução espacial do sistema visual, definida como a recíproca do menor ângulo (mínimo ângulo de resolução) formado entre os detalhes de um objeto que podem ser distinguidos e sua imagem projetada na retina (Smith \& Atchison, 1997). A difração, aberração do olho e a densidade de fotorreceptores e de células ganglionares presentes na retina, são fatores limitantes para a AV. Outros fatores como erro de refração, iluminação do ambiente, contraste e o local em que a retina é estimulada também interferem na AV (Smith \& Atchison, 1997).

A AV pode ser medida de várias formas, dependendo do tipo de tarefa de acuidade utilizada. A sua medição depende de fatores relacionados ao estímulo, à sensação (transformação do estímulo em sinal neural), à transmissão através de vias apropriadas, à percepção (decodificação dos sinais da sensação e sua transformação numa imagem mental) e à cognição (o entendimento do significado dessa imagem) (Bicas, 2002). Um tipo de estímulo comumente usado para medir acuidade visual é uma 
grade de barras pretas e brancas (Fig. 06), cuja frequência espacial é variada até que as listras deixem de ser visíveis.

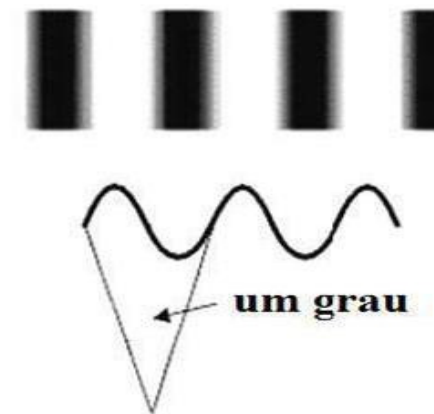

(a)
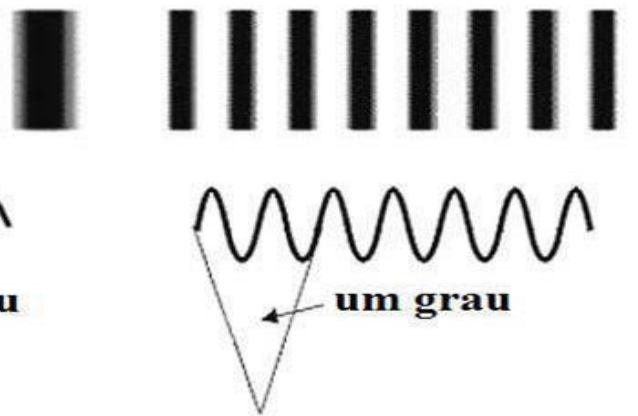

(b)

Figura 06 - A frequência espacial é a medida do número de ciclos formados por grau de ângulo visual. Cada ciclo é formado por uma barra preta e uma branca e a medida é dada em ciclos por grau (cpg). (a) um ciclo por grau; (b) dois ciclos por grau (imagem: http://webvision.med.utah.edu/).

Diferenças ecológicas entre espécies podem indicar variações na resolução espacial, como demonstrado por Lisney \& Collin (2008) que analisaram retinas de diversas espécies de elasmobrânquios (tubarões e raias) e observaram que espécies com resolução espacial mais baixa tendem a ser relativamente menos ativas e se alimentam de invertebrados bentônicos e pequenos peixes, enquanto espécies mais ativas, predadoras que geralmente se alimentam de presas maiores e são mais ativas, possuem resolução espacial maior.

O cálculo da resolução visual espacial leva em consideração o tamanho olho, o poder do cristalino e a densidade de células ganglionares - um método para estimativa da resolução visual que tem sido utilizado em muitas espécies (Hughes, 1975, 1977; Pettigrew et. al., 1988; Pettigrew \& Manger, 2008; Lisney \& Collin, 2008, Hauzman, 2009).

As células ganglionares transmitem a informação visual da retina para os centros superiores. Tais células são em média maiores que os outros neurônios da retina e possuem axônios mielinizados, que transmitem o potencial de ação para as áreas 
superiores do cérebro. As células ganglionares transmitem as mensagens elétricas relacionadas ao sinal visual proveniente dos fotorreceptores processado na camada nuclear interna (Ali \& Klyne, 1985), assim, a densidade e distribuição das células ganglionares na retina, são fatores importantes para a determinação do poder de resolução visual de um individuo. Regiões da retina que possuem alta densidade de células ganglionares são caracterizadas como especializações, havendo maior acuidade visual nestas áreas específicas. Tais especializações podem ser definidas como faixa visual e área centralis, sendo a fóvea uma especialização da área centralis. Serpentes (Hauzman, 2009) e tartarugas (Grötzner; 2005), por exemplo, apresentam faixa visual, gatos possuem área centralis (Rapaport e Stone, 1984) e a fóvea é encontrada em primatas (Schein, 1988). 


\section{Objetivos}

\subsection{Geral}

O objetivo do presente trabalho é analisar os efeitos da intoxicação por metilmercúrio no sistema visual de peixe tropical Hoplias malabaricus submetido a bioensaios de baixas doses agudas.

\subsection{Específicos}

- Analisar células bipolares do tipo $\mathrm{ON}$ imunorreativas a proteína cinase $\mathrm{C} \alpha$;

- Analisar células da camada de células ganglionares coradas com a técnica de Nissl;

- Estimar a acuidade visual do peixe tropical Hoplias malabaricus com base nos valores de densidade de células da camada de células ganglionares;

- Analisar possível influência do $\mathrm{MeHg}$ na acuidade visual do peixe tropical Hoplias malabaricus; 


\section{Material e Métodos}

Para o estudo da toxicidade mercurial no sistema visual do peixe traíra (Hoplias malabaricus), foi utilizado o método de intoxicação aguda por metilmercúrio nas doses de $0,01,0,05,0,1$ e $1,0 \mu \mathrm{g} / \mathrm{g}$ comparadas a um grupo controle. Os procedimentos de intoxicação foram realizados no laboratório de bioensaios da Universidade Federal do Paraná (UFPR), coordenado pelo Prof. Dr. Ciro A. Oliveira Ribeiro. Todos os procedimentos experimentais estão de acordo com as orientações do guia NIH (National Institute of Health) para manejo e uso de animais de laboratório e com as orientações da Sociedade Brasileira de Neurociências e Comportamento (SBNeC).

Tanto os animais do grupo de intoxicação quanto os do grupo controle foram submetidos ao mesmo procedimento de coleta dos olhos, dissecção da retina, imunohistoquímica, coloração de Nissl e análise quantitativa.

\subsection{Intoxicação Aguda}

Os peixes do grupo de intoxicação aguda foram aclimatados por no mínimo dez dias em um tanque com bomba de aeração constante, coberto com grade, contendo tubos de PVC usados como tocas. Após anestesiacom MS222, os peixes foram pesados e separados segundo as doses de metilmercúrio a serem administradas. A manutenção dos animais foi feita através de peixes vivos a cada cinco dias para a alimentação.

A intoxicação foi feita por injeção intraperitoneal na região ventral entre as nadadeiras peitorais e ventrais. Após o procedimento os peixes foram mantidos por mais quinze dias, para depuração do metilmercúrio. Em seguida foi realizada o processamento das retinas para análise. Os animais pertencentes ao grupo controle receberam o mesmo tratamento, porém foi injetado veiculo (água destilada com gotas de metanol - solução utilizada para dissolução do $\mathrm{MeHg}$ ) peritonealmente. 


\subsection{Dissecção das Retinas}

Os peixes utilizados para o experimento agudo com 15 dias de depuração foram adaptados ao escuro por no mínimo 2 horas para ocorrer retração dos grânulos de pigmentos do epitélio pigmentado, e assim, facilitar a visualização ao microscópio das células marcadas por imunohistoquímica e pela técnica de coloração de Nissl. A secção medular e decapitação dos peixes foi realizada, seguida de espinalamento. Logo após foi realizada a enucleação dos olhos, a remoção da íris, córnea e cristalino, obtendo assim a cuia óptica (fig. 07), que foi dissecada sob lupa estereoscópica (Carl Zeiss) para extração da retina que foi fixada em paraformaldeído $4 \%$ (PF) em tampão fosfato $0,1 \mathrm{M}$, pH 7,2 (TF), por três horas. Após a fixação o material foi mantido em $\mathrm{TF}$ a $4^{\circ} \mathrm{C}$, por no mínimo 9 horas. Todo procedimento foi realizado sob luz vermelha tênue, para manter o ambiente com o mínimo de luz possível para evitar a dispersão dos grânulos de pigmento, causada pela adaptação à luz, durante a dissecção. O humor vítreo foi retirado sob lupa estereoscópica (Carl Zeiss), após a fixação, com auxilio de pinça, pincel e microtesouras, mantendo a retina aplanada sobre uma placa de silicone. As retinas ficaram estocadas a $4^{\circ} \mathrm{C}$ até o momento do uso. 


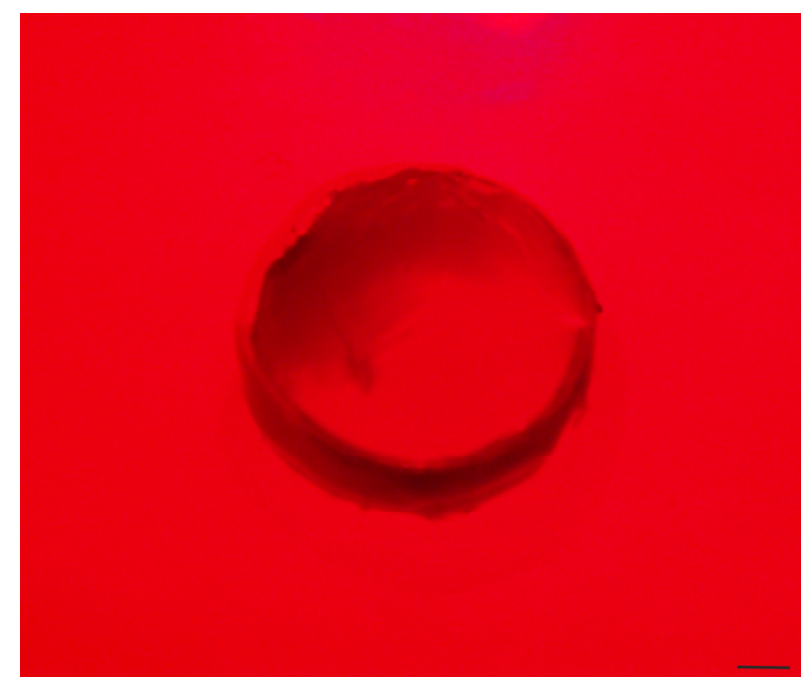

Figura 07 - Foto tirada durante dissecção da retina no laboratório de Histologia da Retina coordenado pela Professora Sonia Grötzner, do departamento de Biologia Celular da UFPR. Escala 2mm.

A identificação do posicionamento retiniano, utilizada para as montagens planas, baseou-se na fissura embrionária formada durante a embriogênese de alguns peixes que apresentam crescimento assimétrico da retina (fig. 08) (Easter, 1992).

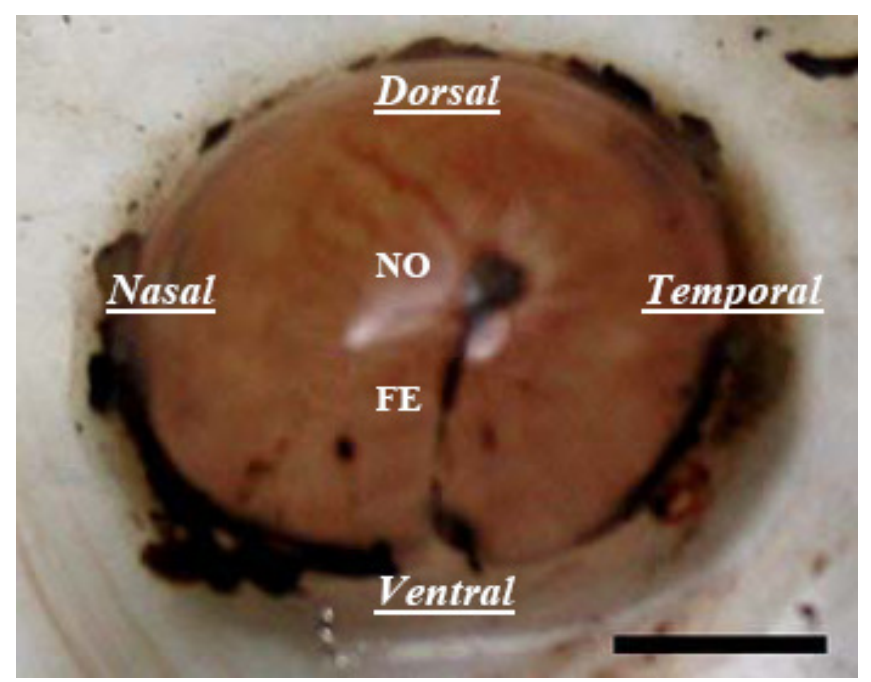

Figura 08 - Retina de um olho esquerdo de Hoplias malabaricus dissecada evidenciando o nervo óptico (NO) e a fissura embrionária (FE). Parâmetros utilizados para a orientação retiniana. Escala: $2 \mathrm{~mm}$. Foto: Sonia Grötzner. 


\subsection{Imunohistoquimica e Coloração de Nissl}

A identificação das células bipolares foi realizada por meio de técnica imunohistoquímica, com o anticorpo anti-proteína cinase C (subtipo alfa - PKC $\alpha$; Sigma; 1:1000) produzido em coelho. O material foi lavado três vezes com TF + triton 0,3\%, cada lavagem com duração de 10 minutos, e em seguida foi feita a incubação da retina no anticorpo primário diluído com $\mathrm{TF}+$ triton $0,3 \%$ por 72 horas. Passado o tempo necessário para incubação foram feitas três novas lavagens com TF + triton $0,3 \%$ de 10 minutos cada e nova incubação do material no anticorpo secundário, IgG anticoelho PKC (produzido em cabra) diluído em TF + triton 0,3\% (1:200, Jackson), acoplado a uma molécula fluorescente, rodamina, por 2 horas. Após a incubação com o anticorpo secundário o material foi lavado com $\mathrm{TF}$ 0,1 M, pH 7,2 (3 lavagens de 10 minutos).

Para montagem plana das retinas foi utilizada uma substância que protege a perda da fluorescência, a parafenilenidiamina $(0,1 \%$, Sigma) diluído em $\mathrm{TF}+$ glicerol (1:1) a $37^{\circ} \mathrm{C}$ (meio de montagem), preparado no mínimo, uma hora antes do uso.

Para análise das células imunorreativas foi utilizado microscópio fluorescente (Leica DM RBE) com câmera digital (Axio CamMR, Carl Zeiss) acoplada a um computador, que permitiu realizar a aquisição de imagens do material analisado através do programa Axio Vision (Carl Zeiss).

A identificação de células da CCG foi realizada pela técnica de coloração de Nissl com corante cresil violeta, através de uma adaptação do protocolo originalmente descrito por Kluver e Barrera (1953). A retina foi aplanada e fixada em uma lâmina gelatinizada, com a qual foi montado um sanduíche usando outra lâmina e papel filtro embebido na solução para sanduíche (formaldeído e etanol 1:9). O sanduiche foi 
mergulhado na solução sanduíche, até ficar submerso, e um peso (com cerca de $250 \mathrm{~g}$ ) foi deixado sobre o sanduíche durante 2 horas. Após esse período a lâmina e o papel filtro foram retirados e a retina aplanada na lâmina gelatinizada passou por soluções alcoólicas e xilol (Tabela anexo 1), em seguida a lâmina foi colocada em solução aquosa de cresil violeta $0,3 \%$ por um tempo médio de 20 a 30 minutos e novamente passou por uma série alcoólica finalizando com xilol puro. As lâminas foram montadas com lamínula e DPX (Sigma).

Para análise das células coradas pela técnica de coloração de Nissl, foi utilizado microscópio (Leica) com câmera digital (Axio CamMR, Carl Zeiss) acoplada a um computador, onde foi possível realizar a aquisição de imagens do material analisado através do programa Axio Vision (Carl Zeiss).

Para análise topográfica e quantitativa, foi feita uma amostragem por toda a retina das células bipolares $\mathrm{ON}$ e células da camada de células ganglionares, em intervalos de no mínimo $1 \mathrm{~mm}$ entre os campos amostrados. A identificação das células foi realizada através das coordenadas x/y, plotadas em uma planilha no programa Excel (Microsoft Corporation). A contagem das células em cada imagem gerada foi obtida com auxílio do programa NIH Scion Image 2.0 (Scion Image Corporation). A retina foi dividida nos quadrantes: ventral, dorsal, nasal e temporal, tendo com pontos de referência o nervo óptico e o início da fissura embrionária a partir do nervo óptico, uma tangente foi traçada por estes pontos, formando um eixo de $0-180^{\circ}$, e a sua perpendicular no eixo de $90-90^{\circ}$ (Cameron \& Easter, 1993) e nas regiões centro e periferia (fig. 9). 


\section{Dorsal}

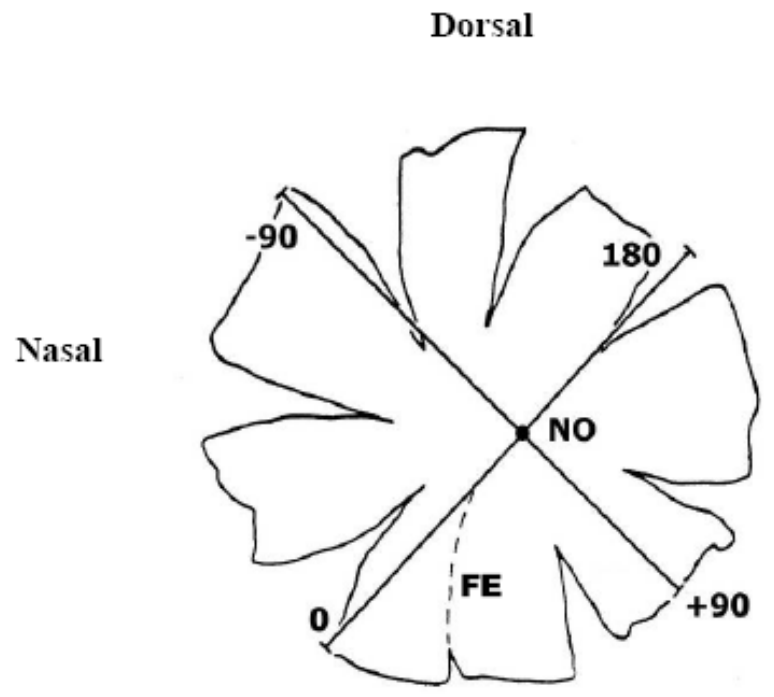

Ventral
A

Temporal

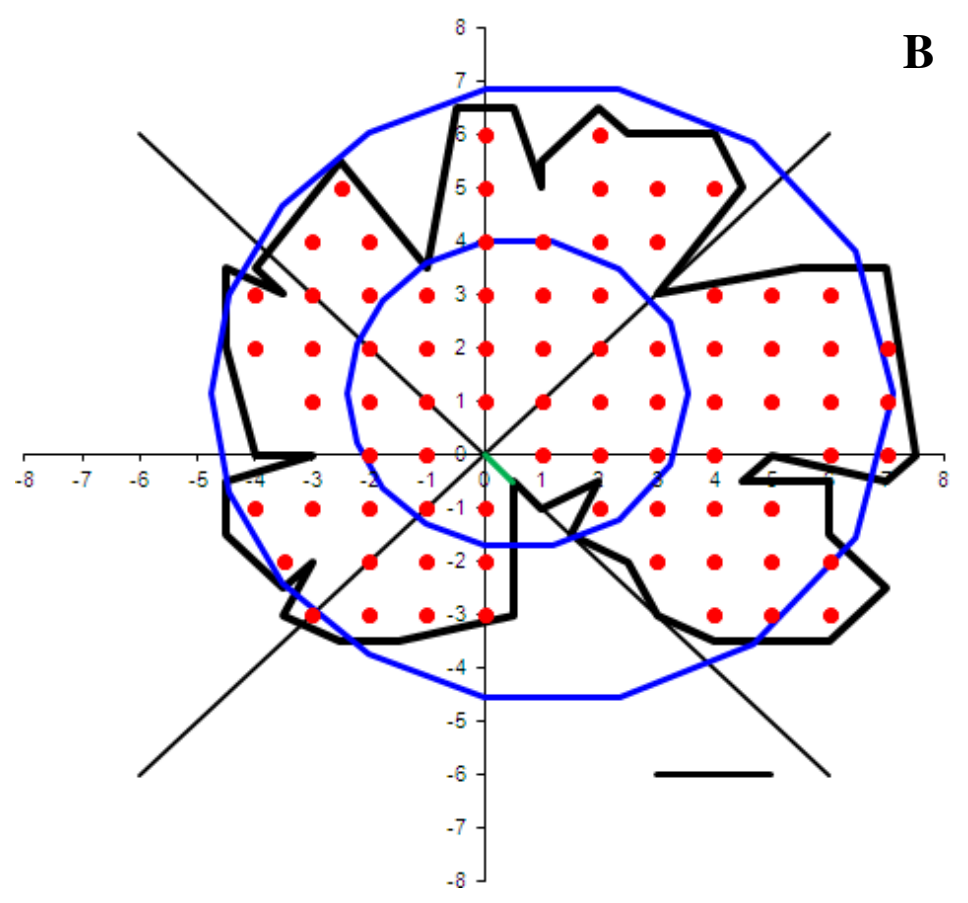

Figura 09 - (A) representação esquemática do sistema de divisão retina em quadrantes, levando-se em consideração o nervo óptico (NO) e o início da fissura embrionária (FE) (Modificado de Cameron e Easter, 1993). (B) Representação esquemática da divisão das retinas em centro e periferia (elipses), campos amostrados (pontos vermelhos) e quadrantes retinianos (tangentes cortando o eixo 0, representado pelo nervo óptico). Escala: $2 \mathrm{~mm}$. 


\subsection{Cortes Histológicos.}

As retinas utilizadas para confecções de cortes radiais foram fixadas e tratadas da mesma forma que as demais. Antes da confecção dos cortes, a retina foi mantida em solução de sacarose $30 \%$, que possui função crioprotetora, a $4^{\circ} \mathrm{C}$ por 4 dias ou até submergir.

Após este período a retina foi aplanada em uma lâmina encapada com laminado de alumínio e emblocada com Tissue-TeK OCT (Sakura, EUA) em gelo seco. A retina aplanada com OCT foi retirada da lâmina encapada com laminado de alumínio e foi então colocada na posição vertical sobre o porta espécime do criostato, onde foi aderida com OCT em gelo seco (foi feito uma espécie de capa em volta da retina utilizando OCT, até formar um bloco). Os cortes com espessura de $10 \mu \mathrm{m}$ foram obtidos a $-25^{\circ} \mathrm{C}$, em criostato (Leica, JUNG GM 3000), pertencente ao Laboratório de Biologia da Retina do Departamento de Biologia Celular e do Desenvolvimento, do Instituto de Biociências I da Universidade de São Paulo, sob Coordenação da Prof ${ }^{a}$ Dra. Dânia Emi Hamassaki e no Criostato (Leica) pertencente ao Laboratório de Neurobiologia do Departamento de Patologia Básica da Universidade Federal do Paraná, coordenado pelo Prof. Dr. Silvio Marques Zanatta.

Os cortes foram colocados em lâminas gelatinizadas (quatro cortes por lâmina), secos em placa aquecedora por 1 hora, a $37^{\circ} \mathrm{C}$ e armazenados em caixas plásticas para lâminas em freezer a $-20^{\circ} \mathrm{C}$ até o momento do uso. Antes da utilização das lâminas, as mesmas, foram colocadas em placa aquecedora ou estufa a $37^{\circ} \mathrm{C}$ por cerca de 20 minutos para retirar o excesso de água proveniente do descongelamento da lâmina.

Os procedimentos de imunohistoquimica realizados nos cortes radiais foram os mesmos realizados para as montagens planas, diferindo o tempo de incubação do 
anticorpo primário (incubado por $12 \mathrm{~h}$ ). Antes da realização dos testes imunohistoquímicos, os cortes foram isolados com uma barreira de esmalte, possibilitando o uso de diferentes concentrações do anticorpo utilizado em uma mesma lâmina. Foi realizado um controle negativo, através da omissão do anticorpo primário (rb anti pkc, Sigma), substituído pela solução de $\mathrm{TF}+\mathrm{T}$ 0,3\%, para verificar se ha existência de marcação inespecífica do anticorpo secundário (gt anti rb IgG TRICT). Todo o processo de imunohistoquímica nos cortes foi realizado em câmara úmida e escura. A montagem da lâmina foi feita com meio de montagem (parafenilenidiamina a 0,001\%, Sigma).

Os cortes foram observados e analisados em microscópio de fluorescência (Leica DM RBE) com câmera digital (Axio CamMR, Carl Zeiss) acoplada a um computador.

\subsection{Cálculo de Acuidade Visual}

Hart (2002) propôs um calculo para estimativa teórica da acuidade visual que se baseia na densidade de células da CCG, o que pode ser considerado como um fator limitante da acuidade visual, e no valor da distância posterior nodal (PND) que é à distância do centro do cristalino até a retina, como mostrado pela linha pontilhada na figura 08. Tal distância é variável de acordo com o tamanho do olho e do cristalino. Em peixes a acomodação do cristalino se dá pela movimentação do mesmo, que chega a invadir a pupila para focalizar um objeto situado mais próximo e se aproxima da retina para focalizar um objeto mais distante. Devido a isso serão calculados dois valores para o PND, como exemplificado pela linha pontilhada na figura 10 A que mostra o cristalino invadindo a pupila e na figura 10 B que mostra o mesmo mais próximo da retina. Assim, à distância $d$ subtendida como um grau na retina pode ser calculada como $d=(2 \pi P N D) / 360$. 

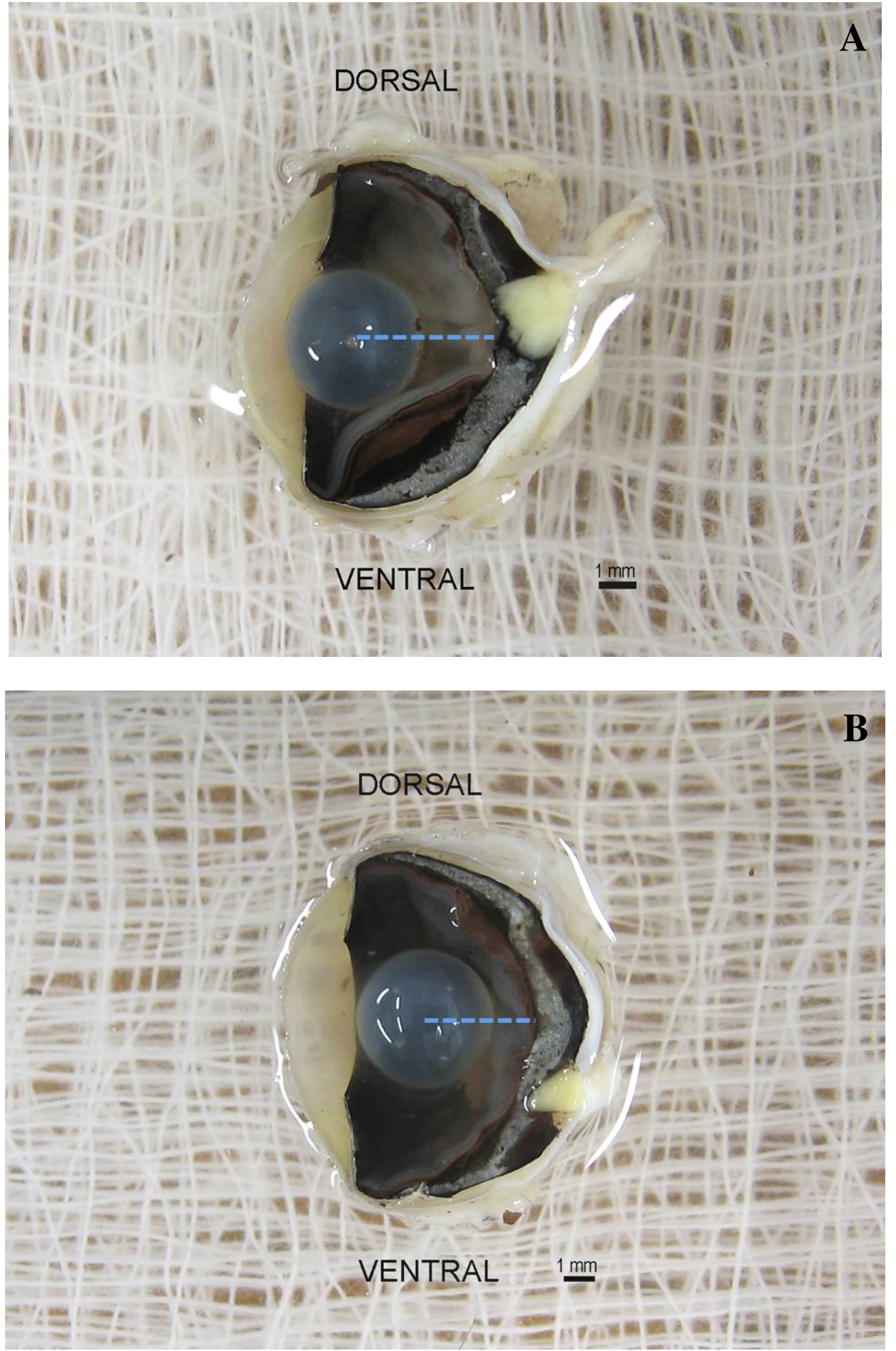

Figura 10 - Corte transversal do olho de traíra (Hoplias malabaricus). A linha pontilhada demarca a distância posterior nodal (do cristalino até a retina). A figura A demonstra o máximo que o cristalino invade a pupila (para focar objetos próximos) e a figura B representa a retração do mesmo (para focar objetos mais distantes) (Imagens: Sonia Grötzner). 
A média de espaçamento intercelular $(S)$ para as células da CCG pode ser determinada pela fórmula $S^{2}=2 /(D \sqrt{ } 3)$, sendo $D$ a densidade celular da CCG em $\mathrm{mm}^{2}$. A frequência espacial máxima $(v)$ de uma grade senoidal que tem resolução com tal arranjo celular (Snyder \& Miller, 1977) é calculada com a fórmula $v=1 /(\mathrm{S} \sqrt{ } 3)$. Para que o poder de resolução espacial (acuidade visual) seja expresso em ciclos por grau (cpg), o valor $v$ é multiplicado pelo valor obtido para $d$.

A estimativa da acuidade visual foi obtida a partir do pico de densidade média de células da CCG de cada retina. Os valores da PND também foram calculados individualmente, a partir do tamanho do globo ocular e do cristalino medido de cada animal. O valor da PND calculado para o cristalino invadindo a pupila para focar um objeto mais próximo, foi calculado como aproximadamente $60 \%$ e o valor para o PND quando o cristalino está mais próximo da retina, para focar um objeto mais distante foi calculado como aproximadamente $35 \%$ do tamanho total do olho. Para realizar os cálculos e definir os valores do PND de acordo com a acomodação do cristalino foram utilizados 7 olhos fixados em paraformaldeido $4 \%$ por 24 horas. Os olhos foram seccionados radialmente, fotografados e o PND foi medido com o auxilio do programa Scion Image (Scion Image Corporation), de acordo com os resultados obtidos com estes 7 olhos foram estimados os valores do PND de acordo com a posição do cristalino, valores estes definidos como 60 e $35 \%$ do tamanho total do olho, com isso é possível estimar o valor do PND para cada olho levando-se em consideração o tamanho do olho, uma vez que não é possível utilizar o mesmo olho para realizar os cálculos de acuidade e a contagem celular realizada por meio de montagens planas da retina.

\subsection{Forma de Análise dos Resultados}

Através dos valores de densidade média é possível confeccionar mapas de isodensidade com auxilio do programa DeltaGraph 4.0, o que permite representar a 
distribuição topográfica das células em cada retina. Para estimativa da população total foi calculada a densidade média $(\mathrm{DM})$ em $\mathrm{mm}^{2}$ de cada campo retiniano amostrado a partir do número total de células contadas em cada campo (n) dividido pela área do campo $\left(A_{\text {campo }}\right)$; multiplicando-se o resultado por $10^{6}$ para transformar a unidade de $\mu \mathrm{m}^{2}$ para $\mathrm{mm}^{2}\left(D M=\left(n / A_{\text {campo }}\right) \times 10^{6}\right)$. Com o valor da DM, a estimativa da população foi calculada através da razão entre $\mathrm{DM}$ e a área do tecido retiniano ( $\left.\mathrm{A}_{\text {retina }}\right)$ estimado em cada quadrante $\left(\right.$ Pop. Total $\left.=D M / A_{\text {retina }}\right)$. A proporção de células foi calculada a partir da soma do número de células contadas em cada quadrante retiniano e dividido pelo número de células em cada retina (ex.: 10.000/60.000 =0,16 $(x 100=16)$. A divisão da retina em quadrantes tem como pontos de referência o nervo óptico e o início da fissura embrionária a partir do nervo óptico. A tangente, traçada por estes pontos forma o eixo de 0 a $180^{\circ}$, e sua perpendicular o eixo de 90 a $-90^{\circ}$, possibilitando a determinação das regiões dorsal, ventral, nasal e temporal, como demonstrado na figura 09.

A análise estatística foi realizada com o teste T-student. 


\section{Resultados}

\subsection{Distribuição das células bipolares imunorreativas a PCK $\alpha$}

Foram analisadas retinas intoxicadas por metilmercúrio nas doses agudas de 0,01 $(\mathrm{n}=4), 0,05(\mathrm{n}=2), 0,1(\mathrm{n}=4)$ e 1,0 $(\mathrm{n}=3) \mu \mathrm{g} / \mathrm{g}$ e um grupo controle $(\mathrm{N}=3)$ (tabela 01$)$.

Tabela 01 - Tamanho, peso e dose de MeHg administrada em cada animal, número de campos amostrados por retina e valores de densidade das células bipolares PKC-IR. Dens.= densidade.

\begin{tabular}{ccccccc}
\hline Bipolares & $\begin{array}{c}\text { Dose de } \\
\text { MeHg } \\
(\boldsymbol{\mu g} / \mathbf{g})\end{array}$ & $\begin{array}{c}\text { Tamanho } \\
\text { do animal } \\
(\mathbf{c m})\end{array}$ & $\begin{array}{c}\text { Peso do } \\
\text { animal } \\
(\mathbf{g})\end{array}$ & $\begin{array}{c}\mathbf{N}^{\circ} \text { de } \\
\text { Campos } \\
\text { amostrados }\end{array}$ & $\begin{array}{c}\text { Dens. Média } \\
\left(\mathbf{c e ́ l} / \mathbf{m m}^{2}\right)\end{array}$ & Densidade \\
TR02 OD & CTRL & 31 & 380 & 166 & $1.595 \pm 314$ & $1.055-2.949$ \\
TR11 OE & CTRL & - & - & 78 & $2.249 \pm 412$ & $1.136-3.220$ \\
TR25 OD & CTRL & 33,5 & 480 & 106 & $1.496 \pm 317$ & $920-2.137$ \\
TR04 OD & 0,01 & - & - & 85 & $1.444 \pm 261$ & $974-2.327$ \\
TR05 OE & 0,01 & 28 & 303 & 80 & $1.175 \pm 345$ & $730-2.056$ \\
TR31 OD & 0,01 & 34,5 & 425 & 80 & $1.521 \pm 411$ & $947-2.706$ \\
TR34 OE & 0,01 & 34 & 310 & 70 & $1.832 \pm 366$ & $1.082-2.679$ \\
TR04 OE & 0,05 & - & - & 52 & $2.326 \pm 461$ & $1.515-3.815$ \\
TR08 OD & 0,05 & 35 & 453 & 176 & $1.346 \pm 293$ & $784-2.191$ \\
\hline TR13 OD & 0,1 & 31 & 325 & 173 & $1.728 \pm 373$ & $1.055-2.895$ \\
TR14 OE & 0,1 & 35 & 465 & 125 & $1.683 \pm 334$ & $1.082-2.624$ \\
TR33 OD & 0,1 & 29 & 275 & 86 & $1.722 \pm 396$ & $1.055-2.814$ \\
TR36 OD & 0,1 & 29 & 261 & 77 & $1.838 \pm 277$ & $1.190-2.435$ \\
TR15 OD & 1,0 & 29,5 & 238 & 89 & $1.945 \pm 306$ & $1.325-2.651$ \\
TR39 OD & 1,0 & 30 & 331 & 107 & $1.556 \pm 333$ & $893-2.300$ \\
\hline
\end{tabular}


Células bipolares do tipo ON com estratificação na sublâmina b da CPI foram imunorreativas ao anticorpo anti-PCK $\alpha$, evidenciando as mesmas características morfológicas de CB do tipo ON na retina da traíra (Fig. 11).
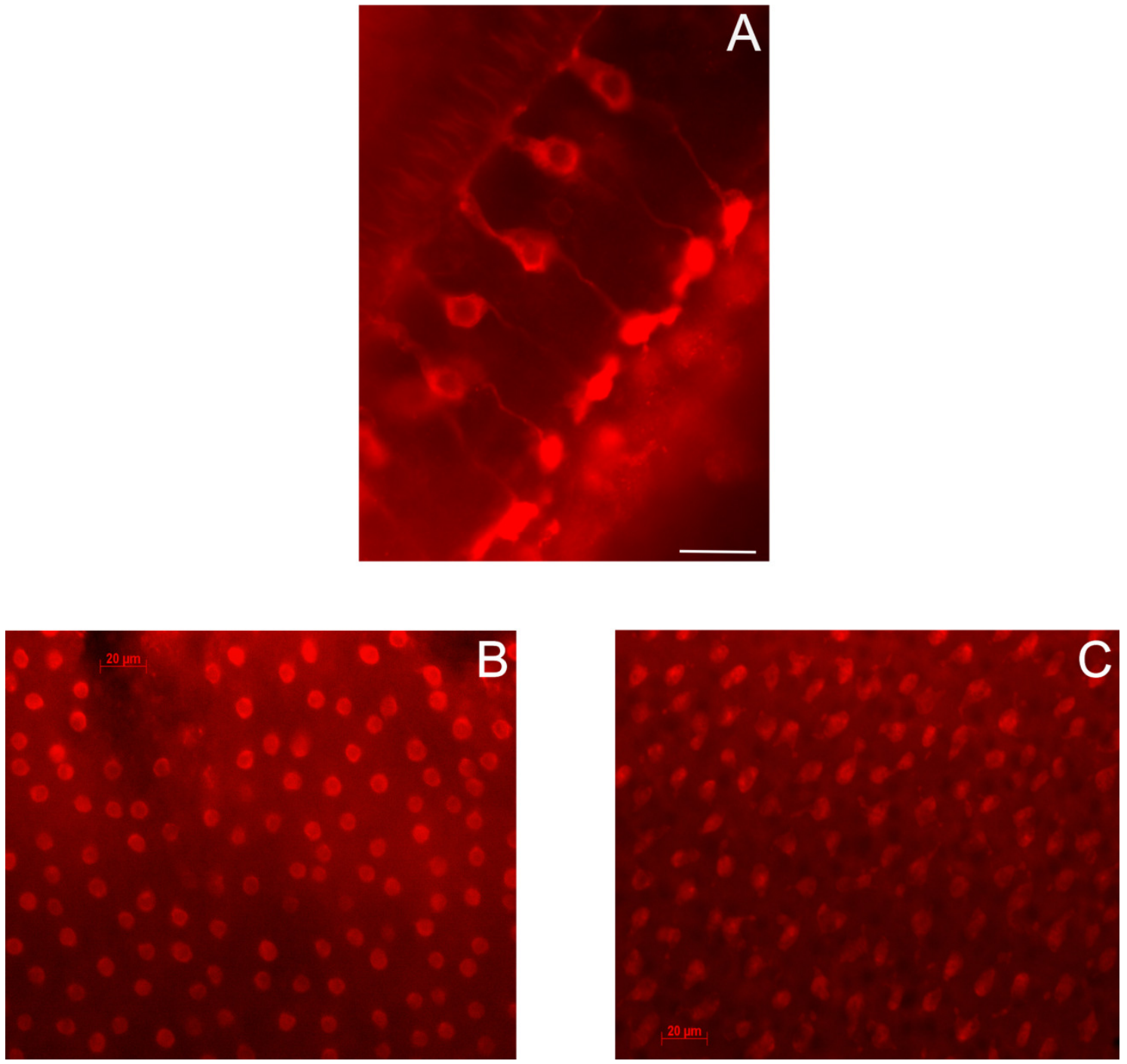

Figura 11 - Imunohistoquímica para proteína kinase C alfa em retina de peixe teleósteo, traíra (Hoplias malabaricus). Secção transversal (A) e montagem plana no nível dos corpos celulares (B) e dos pedículos (C). As imagens B e C correspondem a região central da retina. Escala $20 \mu \mathrm{m}$.

A estimativa da densidade média de células bipolares não apresentou uma redução significativa nas baixas doses agudas testadas (fig.12 A). A análise por região também não mostrou redução significativa (fig. $12 \mathrm{~B}$ e C) ao contrario dos resultados publicados anteriormente por Bonci et al (2006) com altas doses agudas, porém tais 
doses apresentam uma tendência a diminuição do número de células, o que pode ser visto nos mapas de isodensidade (fig. 13)
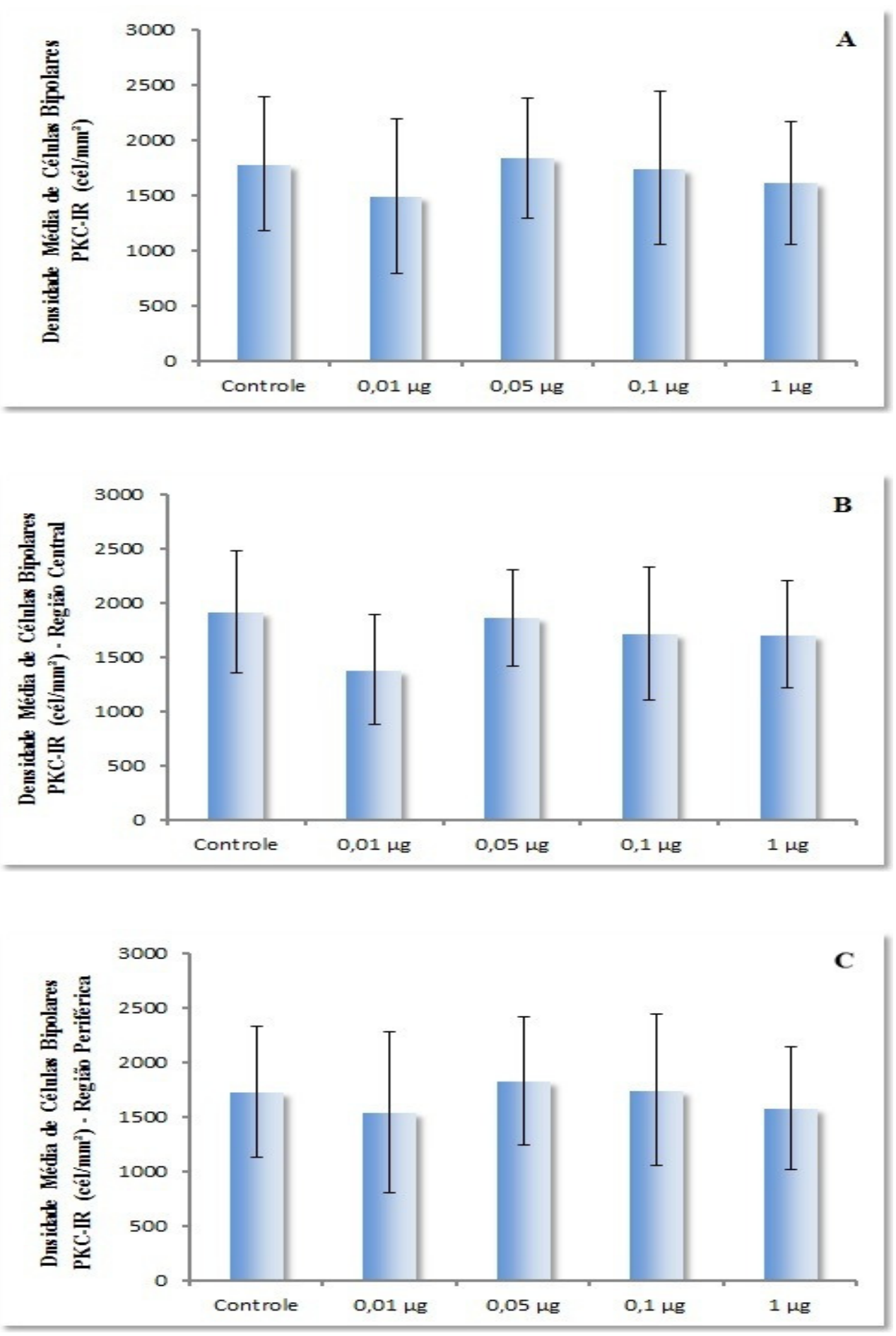

Figura 12 - Estimativa da densidade média de células bipolares ON em retinas controle e intoxicadas (A): região central (B) e região periférica (C). Resultados obtidos com intoxicação de baixas doses agudas. 

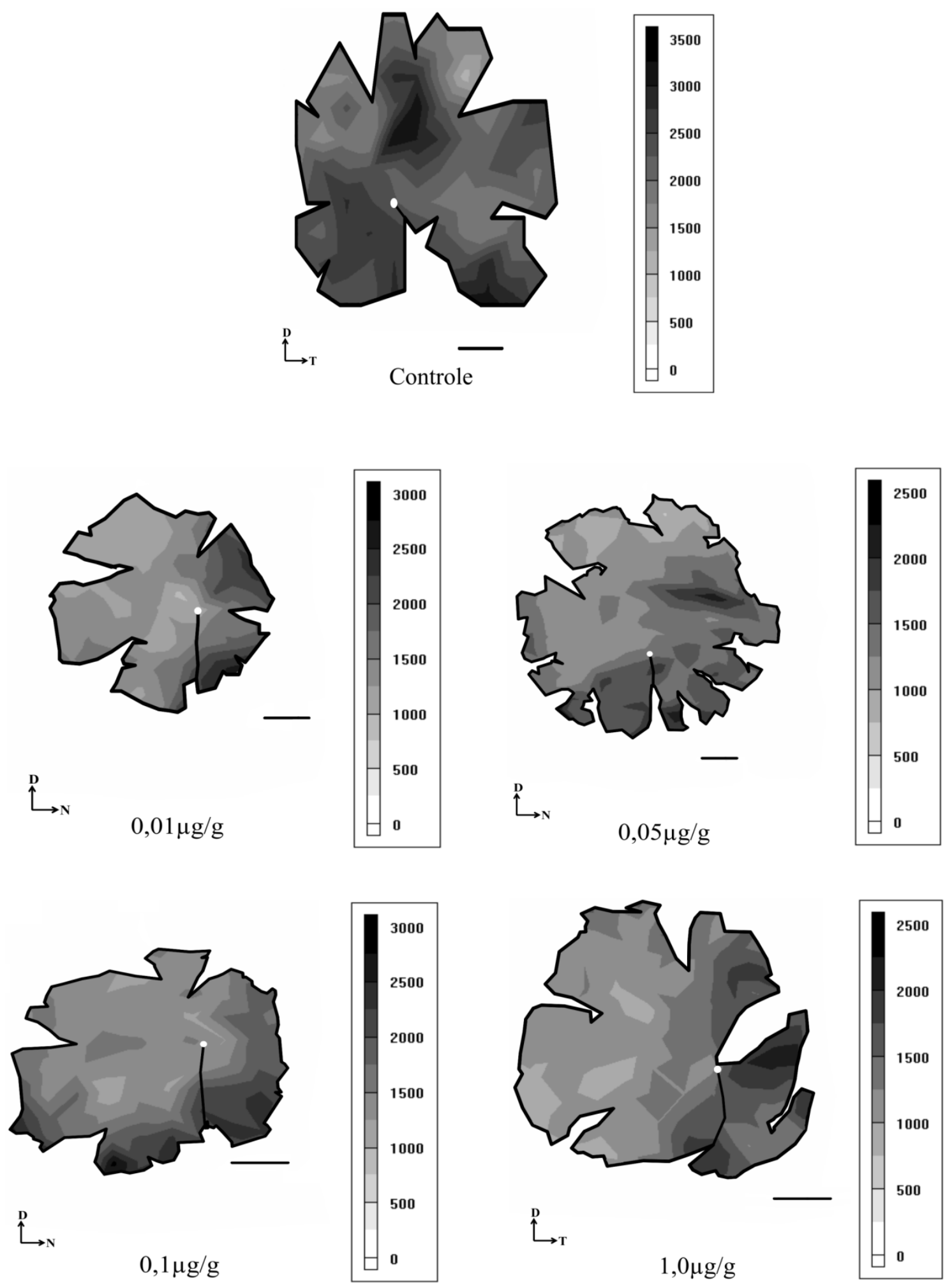

Figura 13 - Mapas de isodensidade de retinas controle (TR11 CTRL OE) e intoxicadas (TR31 0,01 OD, TR08 0,05 OD, TR33 0,1 OD, TR40 1,0 OE), mostrando a distribuição topográfica das células bipolares ON. Escala $2 \mathrm{~mm}$. 


\subsection{Células ganglionares marcadas pela técnica de coloração de Nissl}

Foram analisadas retinas intoxicadas por metilmercúrio nas doses agudas de 0,01 $(n=3), 0,05(n=3), 0,1(n=3)$ e 1,0 $(n=3) \mu \mathrm{g} / \mathrm{g}$ e um grupo controle $(\mathrm{N}=4)$ (tabela 02$)$.

Tabela 02 - Tamanho, peso e dose de MeHg administrada em cada animal, número de campos amostrados por retina e valores de densidade das células da CCG coradas com a técnica de Nissl. Dens.= densidade.

\begin{tabular}{|c|c|c|c|c|c|c|}
\hline $\begin{array}{c}\begin{array}{c}\text { Cél. da } \\
\text { CCG }\end{array} \\
\text { Retinas }\end{array}$ & $\begin{array}{c}\text { Dose de } \\
\text { MeHg } \\
(\mu \mathrm{g} / \mathrm{g})\end{array}$ & $\begin{array}{c}\text { Tamanho } \\
\text { do animal } \\
(\mathrm{cm})\end{array}$ & $\begin{array}{c}\text { Peso do } \\
\text { animal } \\
(\mathrm{g})\end{array}$ & $\begin{array}{c}\mathbf{N}^{\circ} \text { de } \\
\text { Campos } \\
\text { amostrados }\end{array}$ & $\begin{array}{l}\text { Dens. Média } \\
\left(\text { cél } / \mathbf{m m}^{2}\right)\end{array}$ & $\begin{array}{l}\text { Densidade } \\
\text { Min-Max }\end{array}$ \\
\hline TR01 OE & CTRL & 29 & - & 106 & $6.693 \pm 1.238$ & $4.097-11.152$ \\
\hline TR02 OE & CTRL & 31 & 350 & 66 & $4.718 \pm 1.236$ & $2.822-7.191$ \\
\hline TR29 OD & CTRL & 22 & 131 & 142 & $4.140 \pm 723$ & $1.004-6.187$ \\
\hline TR50 OE & CTRL & 34 & 510 & 92 & $5.435 \pm 1.691$ & $3.093-9.634$ \\
\hline TR06 OE & 0,01 & 32 & 394 & 104 & $5.914 \pm 1.484$ & $2.415-10.204$ \\
\hline TR10 OE & 0,01 & 30,5 & 361 & 101 & $3.995 \pm 641$ & $2.632-5.943$ \\
\hline TR31 OE & 0,01 & 34,5 & 425 & 110 & $3.813 \pm 1.163$ & $1.872-7.924$ \\
\hline TR08 OE & 0,05 & 30 & 317 & 70 & $4.076 \pm 1.276$ & $1.628-6.947$ \\
\hline TR18 OE & 0,05 & 28 & 288 & 70 & $5.158 \pm 2.014$ & $1.574-10.285$ \\
\hline TR30 OE & 0,05 & 31 & 351 & 69 & $5.616 \pm 1.812$ & $2.958-13.279$ \\
\hline TR12 OE & 0,1 & 25 & 189 & 58 & $3.393 \pm 1.197$ & $1.519-6.920$ \\
\hline TR13 OE & 0,1 & 31 & 325 & 152 & $4.243 \pm 1.243$ & $1.981-8.792$ \\
\hline TR36 OE & 0,1 & 29 & 275 & 85 & $5.358 \pm 1.302$ & $2.849-11.045$ \\
\hline TR15 OE & 1,0 & 29,5 & 238 & 95 & $4.376 \pm 1.706$ & $1.194-10.122$ \\
\hline TR19 OE & 1,0 & - & - & 64 & $5.065 \pm 1.478$ & 3.012-9.579 \\
\hline TR20 OE & 1,0 & - & - & 58 & $5.562 \pm 1.879$ & $2.523-9.471$ \\
\hline
\end{tabular}


Células da CCG foram coradas com a técnica de Nissl (Fig.14). A técnica evidencia o núcleo de todas as células presentes na CCG (amacrinas deslocadas, glias e ganglionares). Como não podemos afirmar com certeza (somente baseando-se em informações morfológicas como tamanho e formato do núcleo) quais seriam as células ganglionares, todas as células da camada foram quantificadas.

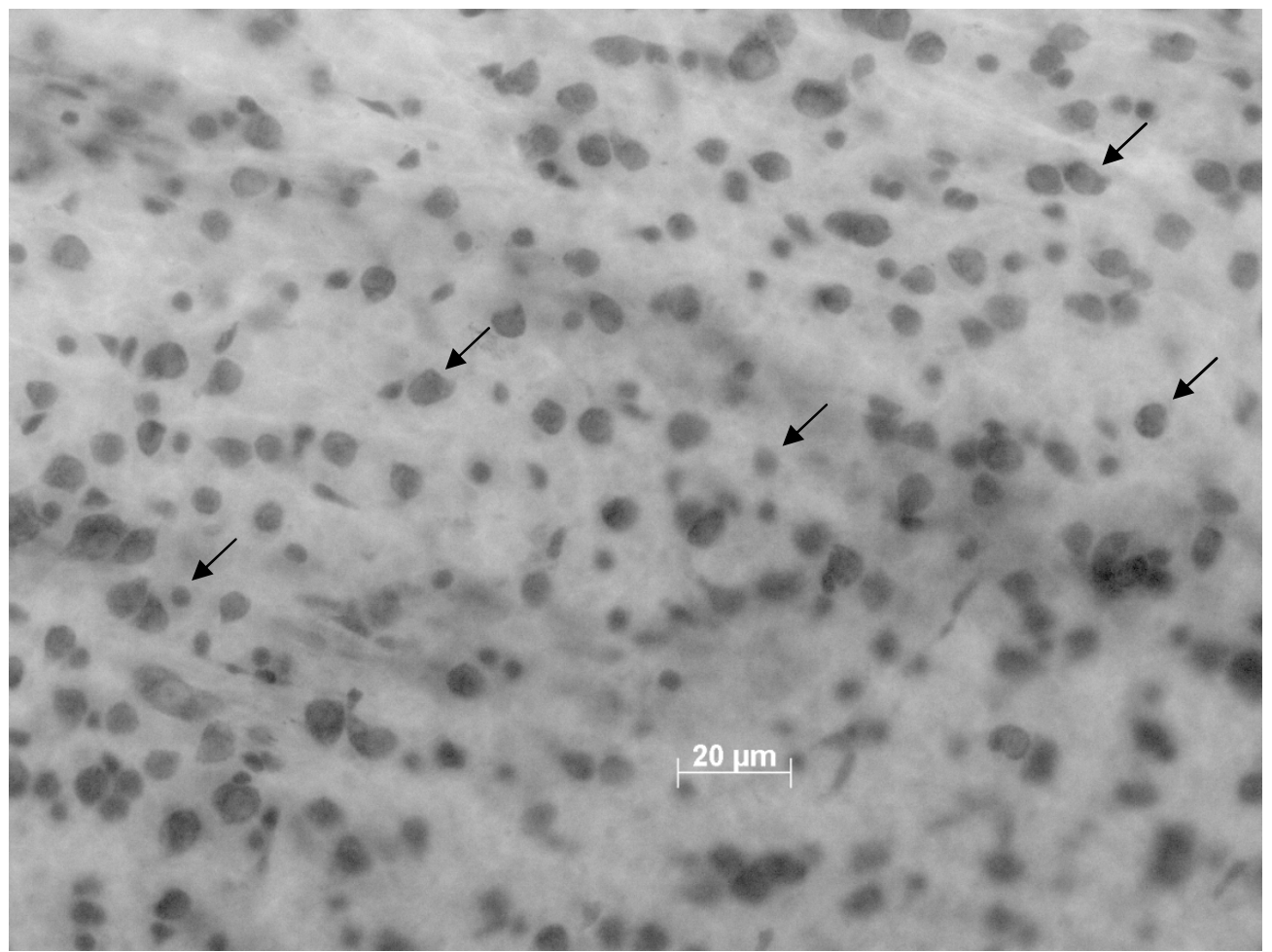

Figura 14 - Fotomicrografia das células da CCG do peixe teleósteo traíra (Hoplias malabaricus), coradas com a técnica de Nissl. Região central. As setas apontam para alguns núcleos celulares. Escala $20 \mu \mathrm{m}$.

Assim como o ocorrido com as células bipolares, a estimativa da densidade média de células da CCG não apresentou perda celular significativa (fig. $15 \mathrm{~A}$ ). A análise por região também não mostrou redução significativa (fig. 15 B e C). Porém, existe uma tendência à diminuição do número de células que também pode ser vista nos mapas de isodensidade das células da CCG (fig. 16). 

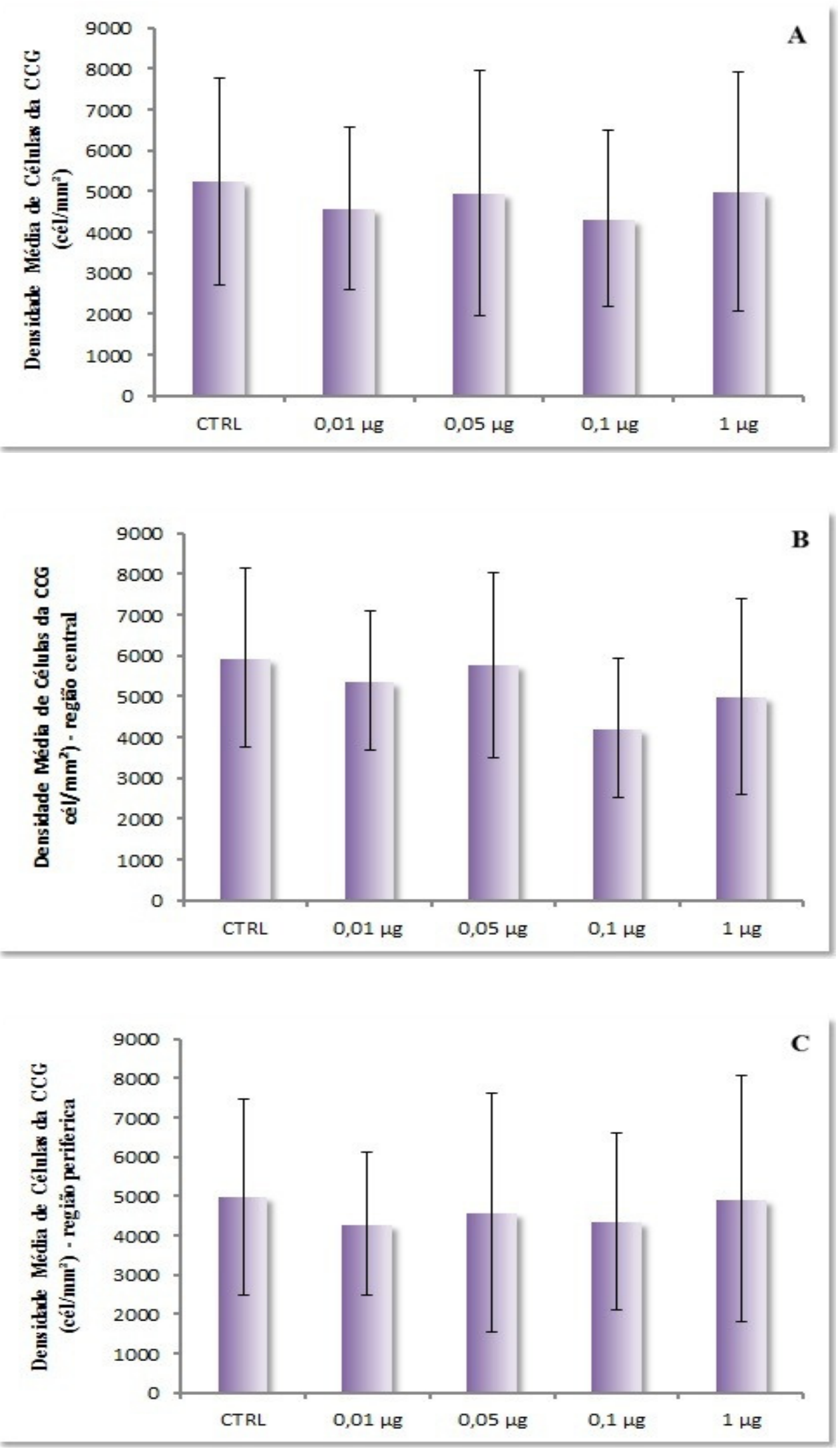

Figura 15 - Estimativa da densidade médiade células ganglionares em retinas controle e intoxicadas (A): região central $(\mathrm{B})$ e região periférica $(\mathrm{C})$. Resultados obtidos com intoxicação de baixas doses agudas. (valor $\mathrm{p}<0,05$, teste $T$-student). 


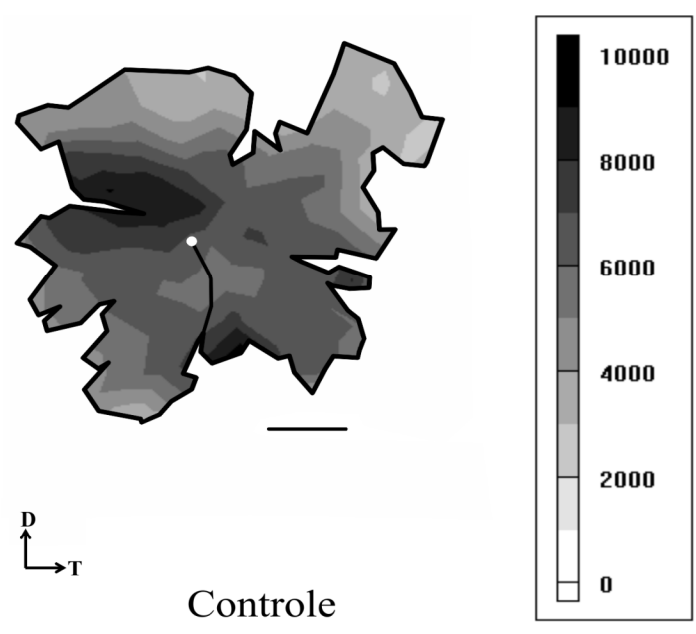

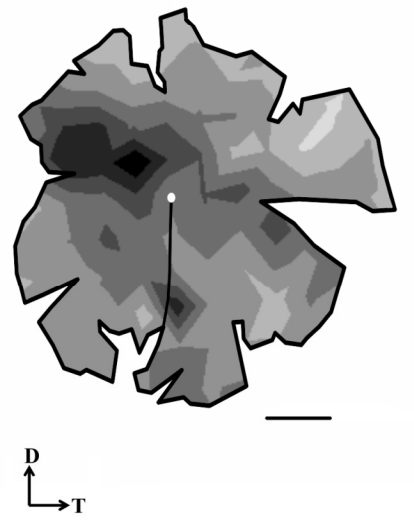

$0,01 \mu \mathrm{g} / \mathrm{g}$

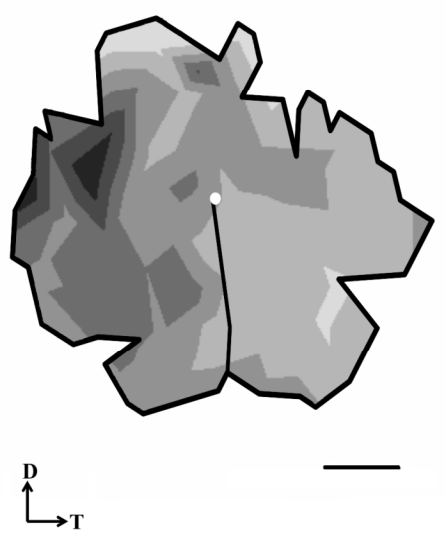

$0,1 \mu \mathrm{g} / \mathrm{g}$
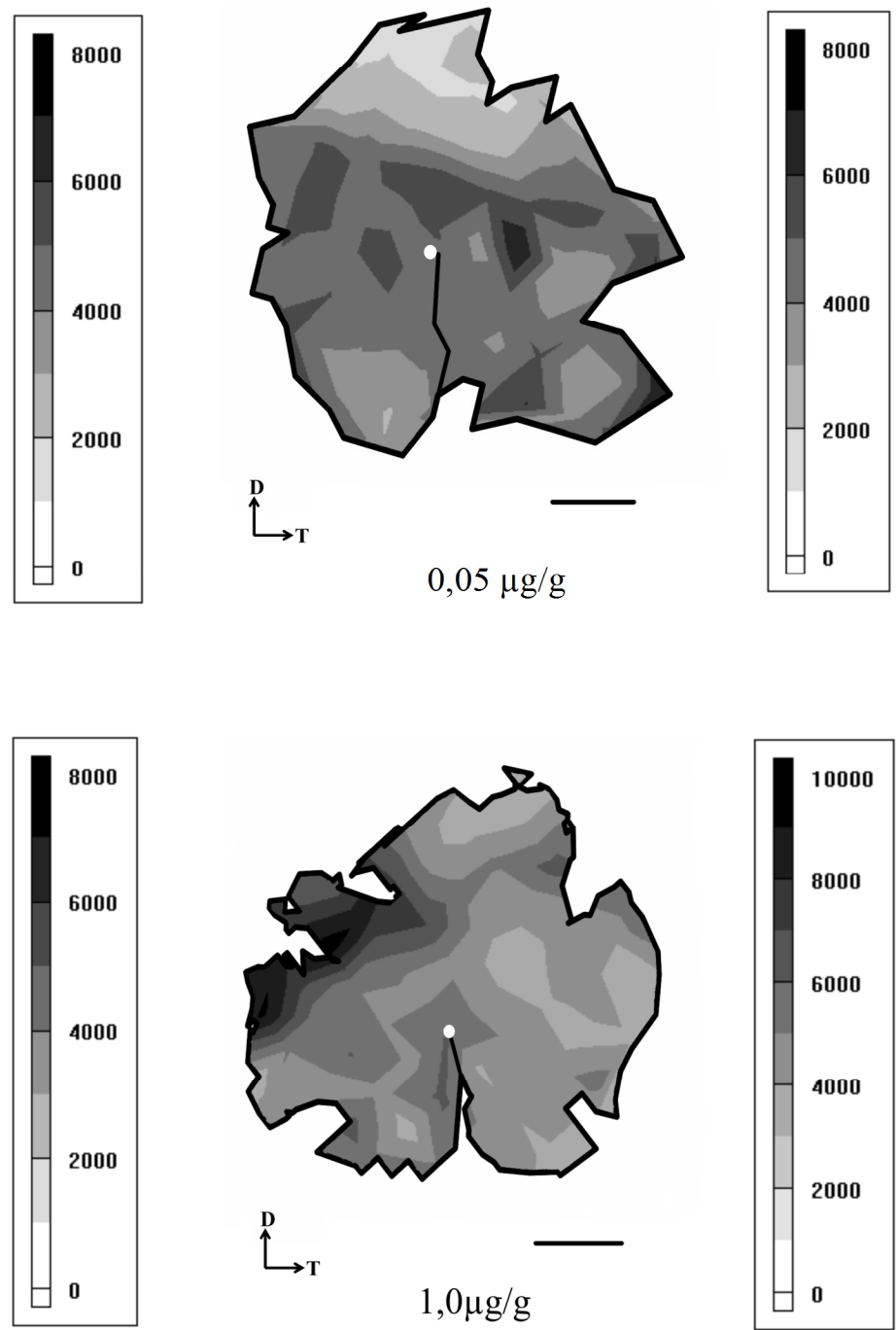

Figura 16 - Mapas de isodensidade de retinas controle (TR50 CTRL OE) e intoxicadas (TR31 0,01 OE, TR08 0,05 OE, TR12 0,1 OE, TR19 1,0 OE), mostrando a distribuição topográfica de células da CCG. Escala $2 \mathrm{~mm}$. 


\subsection{Estimativa da Acuidade Visual}

Os valores de acuidade visual foram calculados com base no pico de densidade de células da CCG, para cada olho. O valor da PND foi calculado a partir do tamanho do globo ocular e do tamanho do cristalino medido para cada olho, e devido ao fato da acomodação do cristalino em peixes se dar pela movimentação do mesmo, foi necessário a realização de dois cálculos para obtenção da PND, um para cada situação de acomodação do cristalino, para perto e para longe, que foram considerados respectivamente como 60 e $35 \%$ do tamanho total do olho (fig. 10). Em seguida foi calculada a distância focal (d), que corresponde a um grau na retina. A frequência espacial máxima (v) foi calculada usando o valor do pico de densidade média (D) de cada retina. Este valor $\mathrm{v}$ foi em seguida multiplicado por d, para expressar o poder de resolução espacial em ciclos por grau (cpg).

A Tabela 3 mostra os valores de acuidade visual e os dos parâmetros envolvidos nesse cálculo para retina controle e retinas de animais submetidos a diferentes doses de intoxicação por metilmercúrio. A acuidade parece não ter sido afetada pela dose de metilmercúrio.

A acuidade visual máxima encontrada para traíra (Hoplias malabaricus) com PND de $60 \%$ foi de 5,94 cpg e a mínima 3,11 cpg. Para PND de 35\% a acuidade máxima foi de 3,46 cpg e a mínima 1,81 cpg (Tabela 03). 
Tabela 03 - Valores calculados da Acuidade Visual para cada retina de Traíra Hoplias malabaricus. DM= densidade media. PND = distância posterior nodal em $\mathrm{mm}$ calculada para cada olho; cpg = resolução espacial em ciclos/grau

\begin{tabular}{|c|c|c|c|c|c|c|c|c|}
\hline $\begin{array}{c}\text { Retina/ } \\
\text { Dose } \\
\text { MeHg } \\
(\mu \mathrm{g} / \mathrm{g})\end{array}$ & $\begin{array}{c}\text { Taman } \\
\text { ho do } \\
\text { animal } \\
\text { (cm) }\end{array}$ & $\begin{array}{c}\mathrm{DM}\left(\mathrm{N}^{\mathrm{o}}\right. \\
* 1000)\end{array}$ & $\begin{array}{c}\text { Pico } \\
\text { Densidade } \\
\text { Max. CCG } \\
\left(\mathrm{N}^{\circ} \text { total }\right)\end{array}$ & $\begin{array}{c}\text { Diâmetro } \\
\text { do olho } \\
(\mathrm{mm})\end{array}$ & $\begin{array}{l}\text { PND } \\
(60 \%) \\
(\mathrm{mm})\end{array}$ & $\begin{array}{l}\text { Resolução } \\
\text { espacial } \\
\text { (cpg) }\end{array}$ & $\begin{array}{l}\text { PND } \\
(35 \%) \\
(\mathbf{m m})\end{array}$ & $\begin{array}{c}\text { Resolução } \\
\text { espacial } \\
\text { (cpg) }\end{array}$ \\
\hline $\begin{array}{c}\text { TR01 } \\
\text { CTRL } \\
\text { 0E }\end{array}$ & 29 & $\begin{array}{c}6.693 \pm 1.2 \\
38\end{array}$ & 11152,53 & 10 & 6 & 5,94 & 3,5 & 3,46 \\
\hline $\begin{array}{c}\text { TR02 } \\
\text { CTRL } \\
\text { OE }\end{array}$ & 31 & $\begin{array}{c}4.718 \pm 1.2 \\
36\end{array}$ & 7191,78 & 9 & 5,4 & 4,29 & 3,15 & 2,50 \\
\hline $\begin{array}{c}\text { TR29 } \\
\text { CTRL } \\
\text { 0D }\end{array}$ & 22 & $\begin{array}{c}4.140 \pm 72 \\
3\end{array}$ & 687,65 & 7,5 & 4,5 & 3,31 & 2,62 & 1,93 \\
\hline $\begin{array}{c}\text { TR50 } \\
\text { CTRL } \\
\text { OE }\end{array}$ & 34 & $\begin{array}{c}5.435 \pm 1.6 \\
91\end{array}$ & 9634,27 & 8 & 4,8 & 4,41 & 2,8 & 2,57 \\
\hline $\begin{array}{c}\text { TR06 } \\
0,01 \text { OE }\end{array}$ & 32 & $\begin{array}{c}5.914 \pm 1.4 \\
84\end{array}$ & 10204,19 & 8 & 4,8 & 4,54 & 2,8 & 2,65 \\
\hline $\begin{array}{c}\text { TR10 } \\
\text { 0,01 OE }\end{array}$ & 30,5 & $\begin{array}{c}3.995 \pm 64 \\
1\end{array}$ & 5943,40 & 8 & 4,8 & 3,47 & 2,8 & 2,02 \\
\hline $\begin{array}{c}\text { TR31 } \\
0,01 \text { OE }\end{array}$ & 34,5 & $\begin{array}{c}3.813 \pm 1.1 \\
63\end{array}$ & 7924,53 & 9 & 5,4 & 4,5 & 3,15 & 2,62 \\
\hline $\begin{array}{c}\text { TR08 } \\
0,05 \text { OE }\end{array}$ & 30 & $\begin{array}{c}4.076 \pm 1.2 \\
76\end{array}$ & 6947,53 & 8 & 4,8 & 3,75 & 2,8 & 2,18 \\
\hline $\begin{array}{c}\text { TR18 } \\
\text { 0,05 OE }\end{array}$ & 28 & $\begin{array}{c}5.158 \pm 2.0 \\
14\end{array}$ & 10285,60 & 8 & 4,8 & 4,56 & 2,8 & 2,66 \\
\hline $\begin{array}{c}\text { TR30 } \\
\text { 0,05 OE }\end{array}$ & 31 & $\begin{array}{c}5.616 \pm 1.8 \\
12\end{array}$ & 13270,87 & 8 & 4,8 & 5,18 & 2,8 & 3,02 \\
\hline
\end{tabular}




\begin{tabular}{|c|c|c|c|c|c|c|c|c|}
\hline $\begin{array}{c}\text { TR12 } \\
\text { 0,1 OE }\end{array}$ & 25 & $\begin{array}{c}3.393 \pm 1.1 \\
97\end{array}$ & 6920,39 & 8 & 4,8 & 3,74 & 2,8 & 2,18 \\
\hline $\begin{array}{c}\text { TR13 } \\
\text { 0,1 OE }\end{array}$ & 31 & $\begin{array}{c}2.243 \pm 1.2 \\
43\end{array}$ & 8792,97 & 7 & 4,2 & 3,69 & 2,45 & 2,15 \\
\hline $\begin{array}{c}\text { TR36 } \\
\text { 0,1 OE }\end{array}$ & 29 & $\begin{array}{c}5.358 \pm 1.3 \\
02\end{array}$ & 11045,49 & 8 & 4,8 & 4,73 & 2,8 & 2,75 \\
\hline $\begin{array}{c}\text { TR15 } \\
\text { 1,0 OE }\end{array}$ & 29,5 & $\begin{array}{c}4.376 \pm 1.7 \\
06\end{array}$ & 10122,77 & 5,5 & 3,3 & 3,11 & 1,92 & 1,81 \\
\hline $\begin{array}{c}\text { TR19 } \\
\text { 1,0 OE }\end{array}$ & - & $\begin{array}{c}5.065 \pm 1.4 \\
78\end{array}$ & 9579,99 & 6,5 & 3,9 & 3,57 & 2,27 & 2,08 \\
\hline $\begin{array}{c}\text { TR20 } \\
1,0 \text { OE }\end{array}$ & - & $\begin{array}{c}5.562 \pm 1.8 \\
79\end{array}$ & 9471,44 & 6 & 3,6 & 3,28 & 2,1 & 1,91 \\
\hline
\end{tabular}




\section{Discussão}

\subsection{Efeitos da Intoxicação Mercurial em Células da CCG e Bipolares PKCa-IR}

O presente trabalho realizou análises de células bipolares $\mathrm{ON}$ e células da CCG de retinas intoxicadas com baixas doses agudas de 0,01, 0,05, 0,1 e 1,0 $\mu \mathrm{g} / \mathrm{g}$ de $\mathrm{MeHg}$ com 15 dias de depuração, comparadas a um grupo controle. Os resultados obtidos foram o inverso aos publicados por Bonci et al. (2006) que analisaram retinas intoxicadas com altas doses agudas (2 e $6 \mu \mathrm{g} / \mathrm{g}$ ). Células bipolares ON e células da CCG não sofreram perdas celulares significativas nas doses de MeHg testadas.

Ao estudar a contaminação por chumbo em humanos e em ratos em desenvolvimento através de medidas eletrofisiológicas com o eletrorretinograma (ERG), Fox et al. (1997) observaram uma diminuição da amplitude de resposta em massa da retina nas funções escotópicas. Tais alterações estariam ligadas a apoptose de bastonetes e células bipolares, acompanhadas por uma redução na atividade enzimática da fosfodiesterase. Ventura et al. (2004) também encontraram alterações na função escotópica ao avaliar pacientes expostos ao mercúrio. Os estudos clínicos se relacionam com os resultados de diminuição do número de células encontrado nas retinas intoxicadas com mercúrio, pois provavelmente essa redução é consequente da indução de morte neuronal pelo mercúrio. Clinicamente, também observou-se, que as funções fotópicas são alteradas em virtude da intoxicação mercurial (Cavalleri et al., 1995; Cavalleri \& Gobba, 1998; Canto-Pereira et al., 2003; Ventura et al., 2003a; Ventura et al., 2003b; Ventura et al., 2003c; Silveira et al., 2004).

O efeito do mercúrio em células nervosas inclui alterações dos canais de cálcio, entre outros, o que aumenta a concentração intracelular de cálcio (Busselberg, 1995; Castoldi et al., 2001), com isso as células vão perdendo a capacidade de se proteger dos 
efeitos da absorção do mercúrio. A morte celular ocorre devido a este fator, acrescido de outros, como aumento do estresse oxidativo, diminuição dos níveis de glutationa e despolimerização de microtúbulos, fatores que por sua vez se tornam cada vez mais prejudiciais. As células neurais necessitam de mecanismos de defesa para prevenir os danos causados, no caso, pela intoxicação mercurial. Porém as mesmas vão perdendo progressivamente a capacidade de se proteger dos efeitos da absorção do mercúrio com o aumento dos níveis de cálcio (Lebel et al., 1990; Sarafian \& Verity 1991; Sarafian 1993; Atchison \& Hare 1994; Sarafian et al., 1994; Oyama et al., 1994; Yee \& Choi 1994; Graff et al., 1997; Okazaki et al., 1997; Castoldi et al., 2001; Bussolaro et al., 2010; Hoffman et al., 2011; Ni et al., 2011; Sura et al., 2011; Lu et al., 2011; Usuki et al., 2011).

O trabalho realizado por Bonci (2006) mostrou que nas doses altas de 2 e $6 \mu \mathrm{g} / \mathrm{g}$ as células não conseguem mais se proteger, podendo ocorrer morte celular por processos necróticos ou apoptóticos. O trabalho realizado por Tanan (2006) contribui para esta explicação, pois o mesmo analisou a atividade eletrofisiológica de células horizontais da retina de traíras intoxicadas nas mesmas doses altas e observou que tais respostas são nulas e em doses menores $(0,01$ e $0,05 \mu \mathrm{g} / \mathrm{g})$ foi observada uma diminuição na amplitude de resposta, que pode ter sido causada pela disfunção dos canais de membrana e incorporação de mercúrio no metabolismo celular. Uma hipótese para o fato de não termos encontrado uma diminuição significativa no número de células em retinas intoxicadas com as baixas doses agudas testadas, seria a de que tais doses necessitariam de um tempo maior de depuração do $\mathrm{MeHg}$ no organismo. Com isso, podermos inferir que mesmo baixas doses agudas de $\mathrm{MeHg}$ seriam prejudicais, necessitando de um tempo maior de depuração, quando comparada as altas doses agudas, para desencadear os efeitos neurotoxicos causados pelo MeHg. Assim, os 
quinze dias de depuração nas baixas doses agudas aqui testadas, não seriam suficientes para alterar os canais de cálcio e ou os níveis de cálcio intracelular a níveis críticos de forma a diminuir a capacidade de proteção das células contra os efeitos da intoxicação e desencadear os efeitos neurotoxicos causados pela absorção do $\mathrm{MeHg}$, que além da disfunção dos canais de cálcio, culmina em outros efeitos ocasionando morte celular. Os resultados eletrofisiológicos obtidos por Tanan (2006) corroboram com essa hipótese, pois nas altas doses agudas com o mesmo tempo de depuração aqui testado, não foi possível registrar respostas eletrofisiológicas em células horizontais da retina da traíra, o que indica que tais células teriam sofrido morte por apoptose ou necrose, enquanto que, em baixas doses agudas, foi evidenciado uma redução da resposta eletrofisiológica nessas células, o que comprova que as mesmas estavam vivas.

Para elucidar tal questão, seria necessário a análise de um n maior, para tornar os resultados mais confiáveis e acima de tudo realizar estudos sobre morte celular, pois uma das causas da diminuição do número de célula devido a intoxicação mercurial é a indução do processo de morte celular apoptótica ou necrótica, tinha-se pensado ainda que pudesse estar ocorrendo uma redução na expressão gênica da proteína, ou seja, as células passariam a expressar uma quantidade menor da mesma (somente quando se trata de reações imunohistoquímicas, como as que realizamos neste trabalho para marcação das células bipolares ON, tal questão não interfere no uso da técnica de Nissl), essa questão foi levanta pelo trabalho realizado por Bonci (2006) que realizou o teste de TUNEL para verificação de morte celular nas altas doses agudas, não obtendo resultados positivos. Podemos excluir tal hipótese no presente trabalho, pois não evidenciamos perdas celulares na população de células bipolares ON imunorreativas a proteína cinase c $\alpha$. 
Estudos sobre morte celular mais específicos, além da técnica de TUNEL se fazem necessário para entender a dinâmica do mercúrio e corroborar os dados aqui encontrados, pois apesar de não ter sido encontrada perda celular significante, foi possível evidenciar através dos mapas de isodensidade, uma mudança topográfica nas retinas intoxicadas em relação ao grupo controle (tanto para as bipolares ON (fig. 13 ) quanto para as células da CCG (fig.16 ), que mostram uma aparente diminuição na densidade celular, , demonstrando haver uma tendência na diminuição celular nas baixas doses agudas, o que pode refletir na interferência do tempo de depuração do MeHg e não somente na quantidade administrada, o que fortalece a hipótese de que as baixas doses agudas causem danos em períodos maiores de exposição. Através de estudos sobre morte celular poderemos evidenciar se nas baixas doses testadas a um inicio de morte celular que irá alcançar seu pico com determinada quantidade de $\mathrm{MeHg}$ ou tempo de exposição. Como Bonci (2006) não conseguiu resultados positivos com a técnica de TUNEL, pode-se inferir que se o processo apoptótico ocorre nas doses agudas, o mesmo já atingiu o máximo de ativação ou em doses mais baixas ou em períodos menores de depuração (nas altas doses) ou em períodos maiores em se tratando de baixas doses ou mesmo que somente o uso do TUNEL não seja a melhor ferramenta de análise. Seria interessante o uso de caspases (família de proteínas envolvidas na iniciação e no termino da morte celular programada), além de outras proteínas atuantes na via apoptótica.

Kunimoto (1994) relacionou os processos apoptóticos e necróticos com a dose de mercúrio administrada, demonstrando a ocorrência de apoptose em cultura de células do cerebelo. A indução de apoptose é dependente da quantidade de mercúrio que afeta o tecido neural, ou seja, até certa dose $(0,1 \mathrm{mM})$ in vitro a morte neuronal seria induzida por processos apoptóticos e acima disto ocorreria morte celular por processos 
necróticos. In vivo, ainda não foram estabelecidos parâmetros para os níveis de mercúrio que diferenciam o início dos processos de morte celular.

Contudo, observamos que as baixas doses testadas não afetam significativamente as células bipolares $\mathrm{ON}$ e células da CCG da retina da traíra, ao contrario do que acontece quando altas doses agudas são administradas. O presente trabalho não esclarece totalmente as questões levantadas, mas indica caminhos a serem seguidos na investigação para o esclarecimento da dinâmica do $\mathrm{MeHg}$ no organismo e se aproxima da ideia de que existiriam limites não prejudiciais de consumo/contaminação por MeHg.

Foi dito anteriormente que o presente trabalho tem como base o trabalho realizado por Bonci (2006), que foi o primeiro a realizar analise morfológica em retina de traíras intoxicadas por $\mathrm{MeHg}$ com doses agudas através de injeções intraperitoneais (sendo o presente trabalho o segundo) e o trabalho realizado por Tanan (2006) analisou eletrofisiologicamente retinas de traíras intoxicadas com as mesmas doses e método de intoxicação utilizados por Bonci (2006). Por esta razão estes dois trabalhos são amplamente citados nesta seção. Trabalhos nesta área são escassos e os efeitos causados pela intoxicação podem variar de acordo com a via de exposição ao MeHg e o tempo de exposição.

\subsection{Acuidade Visual}

Os fotorreceptores são o primeiro um fator limitante para o poder de resolução espacial, porém é a distribuição e a densidade de células ganglionares, que projetam diretamente ao cérebro, através de seus axônios, que colocam um limite adicional e definem o poder de resolução espacial (Van der Meer, 1995; Collin, 1999). 
Entre os métodos para determinação da acuidade visual, o uso da densidade de células ganglionares tem sido utilizado em diversas espécies de vertebrados (Hughes, 1975, 1977, Pettigrew et al., 1988, Hauzman 2009).

Através da técnica de Nissl, não coramos somente as células ganglionares da CCG, mas também amácrinas deslocadas e células gliais, o que pode levar a uma super estimativa do número total de células, e poderia alterar o valor de poder de resolução teórico (Wong \& Hughes, 1987; Collin \& Pettigrew, 1988c; Pettigrew et al., 1988; Bailes et al,.2006).

Contudo, caso seja usado o pico de densidade máxima, tais fatores não interferem significativamente na estimativa teórica da acuidade. $\mathrm{O}$ poder de resolução espacial é expresso como uma medida linear (relacionada à raiz quadrada da densidade celular), assim, a super estimação de células ganglionares em $30 \%$ contribuiria com apenas aproximadamente $6 \%$ para a estimativa final do poder de resolução espacial, que é muito baixo, considerando que a variação entre os indivíduos pode ser maior que $40 \%$ (Pettigrew et al., 1988; Collin \& Pettigrew, 1989), o que valida a técnica (Collin \& Pettigrew, 1989; Wagner et al., 1998). Outro fator que atesta a técnica é o fato de que medidas comportamentais do poder de resolução espacial se aproximam aos resultados obtidos a partir da densidade de células ganglionares (Hughes, 1977; Pettigrew et al., 1988; Collin \& Pettigrew, 1989). 


\section{Conclusão}

Através dos resultados obtidos, podemos concluir que as baixas doses agudas testadas não apresentam efeitos prejudiciais as células bipolares $\mathrm{ON}$ imunorreativas a proteína cinase $\mathrm{C} \alpha$ e as células da CCG marcadas pela técnica de Nissl no tempo de depuração testado,. De acordo com tais resultados a análise da acuidade visual estimada a partir dos cálculos de densidade de células da CCG de Hoplias malabaricus não apresentou relação com as baixas doses agudas de $\mathrm{MeHg}$ testadas. 


\section{Referências Bibliográficas}

Ali, M. A. \& Klyne, M. A. 1985. Vision in vertebrates. Olenum Press, New York, 272p.

Atchison, W. D., Hare, M. F. (1994). Mechanisms of methylmercury-induced neurotoxicity. FASEB J. 8: 622 - 629.

Bailes, H. J.; Trezise, A. E. O. \& Collin, S. P. (2006). The number, morphology, and distribution of retinal ganglion cells and optic axons in the Australian lungfish Neoceratodus forsteri (Krefft 1970). Visual Neuroscience, 23: 257-273.

Barboni, M. T. S., Feitosa-Santana, C., Zachi, E. C., Lago, M., Teixeira, R. A. A., Taub, A., Costa, M. F., Silveira, L. C. L., Ventura, D. F. (2009). Preliminary findings on the effects of occupational exposure to mercury vapor below safety levels on visual and neuropsychological functions. Journal of Occupational and Environmental Medicine. 51: $1403-1412$.

Barboni, M. T. S., Costa, M. F., Moura, A. L. A., Feitosa-Santana, C., Gualtieri, M., Lago, M., Faria, M. A. M., Silveira, L. C. L., Ventura, D. F. (2008). Visual field losses in workers exposed to mercury vapor. Environmental Research (New York). 107: 124 131.

Bear, M, F., Connors, B, W., Paradiso, M. A. Neurociências: Desvendando o Sistema Nervoso. $2^{\mathrm{a}}$ ed. Porto Alegre: Artmed, 2002.

Bicas, H. E. (2002). A Acuidade visual. Medidas e notações. Arq Bras Oftalmol. 65(3): $375-384$.

Bisinoti M. C.; Jardim W. F. (2004). O Comportamento do Metilmercúrio (METILHg) no Ambiente. Quim. Nova. 27(4): 593 - 600. 
Boening D, W. (2002). Ecological Effects, Transport, and Fate of Mercury: A General Review. Chemosphere. Jun; 40(12): 1335-51.

Bonci, D. M. O. (2006). Análise de Células Amácrinas PV-IR e Bipolares PKC-IR em Retina de Peixe Tropical (Hoplias malabaricus) Intoxicado com metilmercúrio. Dissertação de Mestrado, Instituto de Psicologia, Universidade de São Paulo, São Paulo.

Bonci, D. M. O., Lima, S. M., Grötzner, S. R., Ribeiro, C. A., Hamassaki, D. E., ventura, D. F. (2006). Losses of Immunoreactive Parvabulmin Amacrine and Immunoreactive Alphaprotein Kinase C Bipolar Cells Caused by Methylmercury Choride Intoxication in the Retina of the Tropical Fish Hoplias Malabaricus. Brazilian Journal of Medical and Biological Research. 39: 405-10.

Bowmaker, F, K. (1991). The Evolution of Vertebrate Visual Pigments and Photoreceptors. In: Vision and Visual Dysfunction: Evolution of the Eyes and Visual System. Editores: John R., Cronly-Dilion e Richard L., Gregory, Macmillan Press Ltd. 2:399-420.

Boycott, B. B., Wassle H. (1974). The morphological types of ganglion cells of the domestic cat's retina. J. Physiol. Jul. 240(2):397-419.

Brabo, E. S., Santos, E. O., Jesus, I. M., Mascarenhas, A. F., Faial, K. (2000). Mercury Contamination of Fish and Exposures Indigenous Community in Pará State, Brazil. Academic Press, p. 197-203.

Burbacher, T. M., Grant, K. S., Mayfield D. B., Gilbert, S. G., Rice, D. C. (2005). Prenatal Methylmercury Exposure Affects Spatial Vision in Adult Monkeys. Toxicol Appl Pharmacol. Oct 1; 208(1): 21-28. 
Bussolaro, D., Filipak Neto, F., Oliveira Ribeiro, C. A. (2010). Responses of hepatocytes to DDT and methyl mercury exposure. Toxicology in Vitro. 24: 1491-1497.

Cajal, S. R. (1893). Lá Retine dês Vertebrés. La Cellule. 9: 17-257.

Cameron, D. A., Easter S. S. (1993). The cone photoreceptor mosaic of the green sunfish, Lepomis cyanellus. Vis. Neurosci. Mar-April; 10(2): 375-84.

Caminos, E., Velasco, A., Jarrin, M., Lillo, C., Jimeno, D., Aijon, J., Lara, J, M. (2000). A Comparative Study of Protein Kinase C-like Immunoreactive Cells in the Retina. Brain Behav Evol. Dec; 56(6): 330-339.

Caminos, E., Velasco, A., Jarrin, M., Aijon, J., Lara, J. M. (1999). Protein kinase C- like Immunoreactive Cells in Embryo and Adult Chicken Retinas. Brain Research: Developmental Brain Research. 118(1-2): 227-30.

Canto-Pereira, L. H. M., Lago, M., Costa, M. F., Rodrigues, A. R., Saito, C., Silveira, L. C. L., Ventura D. F. (2005). Visual Impairment on Dentists Related to Ocupational Mercury Exposure. Environmental Toxicology and Pharmacology. 19: 517 - 522.

Canto-Pereira, L. H. M., Simões, A. L., Lago, M., Moura, A. L. A., Costa, M. F., Rodrigues, A., SATO, C., Faria, M. A. M., Silveira, L. C. L., Ventura, D. F. (2003). Ocupational Exposure to $\mathrm{HgO}$ Impairs Visual Functions in Dentists and Factory Workers in Brazil. Proceedings of the 9th Meeting the International Neurotoxicology Association (INA), p. 87.

Carta, P., Flore, C., Alinovi, R., Ibba, A., Tocco, M. G., Aru, G., Carta, R., Girei, E., Mutti, A., Lucchini, R., Randaccio, F. S. (2003). Sub-clinical neurobehavioral abnormalities associated with low level of mercury exposure through fish consumption. Neurotoxicol. 24: 617-623. 
Castoldi, A, F., Coccini, T., Ceccatelli, S., Manzo, L. (2001). Neurotoxicity and molecular effects of methylmercury. Brain Research Bulletin. 55(2): 197-203.

Castoldi, A, F., Coccini, T., Manzo, L. (2003). Neurotoxic and Molecular Effects of Methylmercury in Humans. Reviews on Environmental Health. 18: 19-31.

Cavalleri, A., Belotti, L., Gobba, F., Luzzana, G., Rosa, P., Saghizzi, P. (1995). Colour Vision Loss in Workers Exposed to Elemental Mercury Vapour. Toxicol Lett. May; 77(1-3): 351-6.

Cavalleri, A., Gobba, F. (1998). Reversible Color Vision Loss in Ocupational Exposure to Metallic Mercury. Environ. Res. May; 77(2): 173-7.

Collin, S.P. (1999). Behavioural ecology and retinal cell topography. In: Adaptive Mechanisms in the Ecology of Vision (Archer, S.N.; Djamgoz M.B.A.; Loew E.R., Partridge, J.C., Vallerga, S. eds). Dordrecht: Kluwer Academic Publishers. pp. 509535.

Collin, S. P. \& Pettigrew, J. D. (1988). Retinal ganglion cell topography in teleosts: a comparison between Nissl-stained material and retrograde labelling from the optic nerve. J. Comp Neurol, 276: 412-422.

Collin, S. P. \& Pettigrew, J. D. (1989). Quantitative comparison of the limits on visual spatial resolution set by the ganglion cell layer in twelve species of reef teleosts. Brain Behav Evol, 34: 184-192.

Costa, M. F., Tomaz, S., Souza, J. M., Silveira, L. C. L., Ventura, D. F. Electrophysiological evidence for impairment of contrast sensitivity in mercury vapor occupational intoxication. (2008). Environmental Research (New York). 107: 132 - 138. Costa, G. M., Anjos, L. M., Souza, G. S., Gomes, B. D., Saito, C. A., Pinheiro, M. C. 
N., Silva Filho, M., Ventura, D. F., Silveira, L. C. L. (2008). Mercury toxicity in Amazon gold miners: Visual dysfunction assessed by retinal and cortical electrophysiology. Environmental Research (New York). 107:98 - 107.

Cunningham, J. G. Tratado de Fisiologia Veterinária. Rio de Janeiro: Guanabara Koogan, 1993.

Damin, E. T. B. Alterações Psicofísicas do Sistema Visual Humano Relacionados à Exposição ao Mercúrio. Tese de Doutoramento no Curso de Pós-graduação em Ciências Biológicas. Belém: Universidade Federal do Pará (UFPA), 2000.

Easter, S. S. Jr. (1992). Retinal Growth in Foveated Teleosts: Nasotemporal Asymmetry Keeps the Fovea in Temporal Retina. The Journal of Neuroscience. 12(6): 2381-92.

Feitosa-Santana, C., Barboni, M. T. S., Oiwa, N. N., Paramei, G. V., Simões, A. L. A. C., Costa, M. F., Silveira, L. C. L., Ventura, D. F. (2008). Irreversible color vision losses in patients with chronic mercury vapor intoxication. Visual Neuroscience. .25: $487-491$.

Feitosa-Santana, C., Costa, M. F., Lago, M., Ventura, D. F. (2007). Long-term loss of color vision after exposure to mercury vapor. Brazilian Journal of Medical and Biological Research. 40(3): 409 - 414.

Fonnum, F., Lock, E. A. (2000). Cerebellum as a Target for Toxic Substances. Toxicol Lett. Mar 15; 112-113: 9-16.

Famiglietti, E. V. Jr., Kolb, H. (1976). Structural basis for ON-and Off-center responses in retinal ganglion cells. Science. Oct8:194 (4261):193-195.

Filipakneto, F., Zanata, S., Silva de assis, H., Nakao, L., Randi, M ., Oliveira Ribeiro, C. (2008). Toxic effects of DDT and methyl mercury on the hepatocytes from Hoplias malabaricus. Toxicology in Vitro, 22: 1705-1713. 
Fukuda, K., Saito, N., Yamamoto, M., Tanaka, C. (1994). Immunocytochemical Localization of the alpha-, beta I-, beta II- and gamma-subspecies of protein kinase C in the monkey visual pathway. Brain Research. 658(1-2): 155-62.

Fyk-kolodziej, B., CAI, W. Pourcho, R, G. (2002). Distribution of Protein Kinase C Isoforms in the Cat Retina. Visual Neuroscience. 19(5): 549-562.

Gabriel, R., Lesauter, J., Silver, R., Garcia-espana, A., Witkovsky, P. (2001). Diurnal and Circadian Variation of Protein Kinase C Immunoreactivity in the Rat Retina. The Journal of Comparative Neurology. 439(2): 140-50.

Gitter, S., Pardo, A., Kariv, N., Yinon, U. (1988). Enhanced Electroretinogram in Cats Induce by Exposure to Mercury Acetate. Toxicology, 51: 67-76.

Graff, R. D., Falconer, M. M., Brown, D. L., Reuhl, K, R. (1997). Altered sensitivity of posttranslationally modified microtubules to methylmercury in differentiating embryonal carcinoma-derived neurons. Toxicol. Appl. Pharmacol. 144: 215-224.

Grandjean P. (1999). Mercury risks: Controversy or just uncertainty. Public Health Reports. 114: 512-515.

Greferath, U., Grunert, U., Wassle, H. (1990). Rod Bipolar Cells in the Mammalian Retina Show Protein Kinase C-like Immunoreactivity. The Journal Of Comparative Neurology. 301(3): 433-42.

Grötzner, S. R. Densidade e topografia dos fotorreceptores da retina da tartaruga Trachemys scripta elegans com imunocitoquímica de opsinas. 2005. São Paulo: s.n., 2005. - 185p. Tese (doutorado) - Instituto de Psicologia da Universidade de São Paulo. 
Grunert, U., Martin, P, R. (1991). Rod Bipolar Cells in the Macaque Monkey Retina:Immunoreactivity and Connectivity. The Journal of Neuroscience. 11(9): 274258.

Hart, N, S. (2002) Vision in the peafowl (Aves: Pavo cristatus). The Journal of Experimental Biology, 205: 3925-3935.

Hart, N, S., Lisney, T, J., Marshall, N, J., Collin, S, P. (2004). Multiple Cone Visual Pigments and the Potential for Trichromatic Colour Vision in Two Species of Elasmobranch. J. Exp. Biol. DEC; 207(Pt 26): 4587-94.

Hauzman, E. (2009). Estudo Comparativo da Densidade e Topografia de Neurônios de Retinas de Philodryas olfersii e P. patagoniensis. Dissertação de Mestrado, Instituto de Psicologia, Universidade de São Paulo, São Paulo.

Haverkamp, S., Haeseleer, F., Hendrickson, A. (2003). A Comparison of Immunocytochemical Markers to Identify Bipolar Cell Types in Human and Monkey Retina. Visual Neuroscience. 20(6): 589-600.

Hawryshyn, C. W., Mackay, W. C., Nilsson, T. H. (1982). Methyl Mercury Induced Visual Deficits in Rainbow Trout. Canadian Journal of Zoology, 60 (12): 3127-3133.

Hawryshyn, C. W. Vision. In: The Physiology of Fishes. Editor: Evans D. H. $2^{\circ}$ ed. EUA: CRC Press, 1997.P. 345-374.

Hawryshyn, C. W., Mackay, W. C. (1979). Toxicity and Tissue Uptake of Methylmercury Administered Intraperitoneally to Rainbow Trout (Salmo Gairdneri Richardson). Bull Environ Contam Toxicol. Sep; 23(1-2): 79-86. 
Helberg, J. \& Hystrom, M. 1972. The influence of methylmercury exposure on learning set behavior of squirrel monkeys. Psychol. Res. Bull. 3: 11-17.

Hoffman, D. J., Eagles-Smith, C. A., Ackerman, J. T., Adelsbach, T. L., Stebbins, K. R. (2011). Oxidative stress response of forster's terns (sterna forsteri) and caspian terns (hydroprogne caspia) to mercury and selenium bioaccumulation in liver, kidney, and brain. Environ. Toxicol. Chem. 30(4):920-929.

Hughes, A. (1975). A quantitative analysis of the cat retinal ganglion cell topography. The Journal of Comparative Neurology, 163: 107-128.

Hughes, A. (1977). The topography of vision in mammals of contrasting life styles: comparative optics and retinal organization. In The Visual System in Vertebrates: Handbook of Sensory Physiology. Vol. VII/5. Ed. Crescitelli, F., 613-756. Belrlin, Heidelberg: Springer.

Igata, A. Epidemiological and Clinical Features of Minamata Disease. Environ. Res. Oct; 63(1): 157-69. 1993.

Job, C., Lagnado, L. Calcium and Protein Kinase C Regulate the Actin Cystoskeleton in the Synaptic Terminal of Retina Bipolar Cells. J. Cell Biol. Dec; 143(6): 1661-72. 1998.

Joselevitch, C. (2005). The twiligth zone. How mixed-input bipolar cells process rod and cone signals. Tese de Doutorado, Universiteit Van Amsterdam, Fedodruk.

Kaneko, A. (1970). Physiological and Morphological Identification of Horizontal, Bipolar and Amacrine Cells in Goldfish Retina. The Journal of Physiology. 207(3): 623-33. 
Kandel, E. R., Schwartz, J. H., Jessell, T. M. Princípios da Neurociência. $4^{\text {a }}$ ed. Barueri - SP: Manole, 2003.

Kaplan, E., Shapley, M. R. (1986). The primate retina contains two types of ganglion cells, with high and low contrast sensitivity. Neurobiology. 83. 2755-2757.

Kehring, H. A., Costa, M., Moreira, I. \& Malm, O. 2002. Total and methylmercury in a Brazilian estuary, Rio de Janeiro. Mar. Pollu. Bull. 44: 1018-1023

Kjellstrom, T., Kennedy, P., Wallis, S., Stewart, A., Friberg, L., Lino, B., Witherspoon, T. \& Mantell, C. 1989. Physical and metal developed of children with prenatal exposure to mercury from fish. National Swedish Environment Protect Board Report. 3642: 7589.

Kingman, A., Albers, J, W., Arezzo, J, C., Garabrant, D, H., Michalek, J, E. (2005). Amalgam exposure and neurological function. Neurotoxicology. 26(2): 241-55.

Kluver, H., Barreira, E. (1953). A Method for the Conbined Staining of Cells and Fiber in the Nervous System. J. Neuropathol. Exp. Neurol., 12: 400-403.

Koistimanho, J., Sagar, S, M. (1994). Localization of Protein kinase C Subspecies in the Rabbit Retina. Neuroscience Letters. 177(1-2): 15-18.

Kolb, H., Zhang, L., Dekorver, L. (1993). Differential Staining of Neurons in the Human Retina With Antibodies to Protein Kinase C Isozymes. Visual Neuroscience. 10(2): $341-51$.

Kosaka, J., Suzuki, A., Morii, E., Nomura, S. (1998). Differential Localization and Expression of Alpha and Beta Isoenzymes of Protein Kinase $\mathrm{C}$ in the Rat Retina. Neuroscience Research. 54(5): 655-63. 
Kunimoto, M. (1994). Methylmercury induces apoptosisof rat cerebellar neurons in primary culture. Biochem Biophys Res Commun. Oct14;204(1):310-317.

Kraaij, D. A. (2000). Spectral and dynamic properties of cones/horizontal cell interaction in goldfish retina. Academisch Proefschrift. 125p.

Lago, M. (2005). Sensibilidade ao Contraste Espacial de Luminancia e Cromático em Pacientes Intoxicados por Vapor de Mercúrio: Evolução Após Dois Anos. Dissertação de Mestrado em Neurociências e Comportamento, Instituto de Psicologia, Universidade de São Paulo, São Paulo.

Lebel, J., Mergler, D., Branches, F., Lucotte, M., Amorim, M., Larribe, F., Dolbec, J. (1998). Neurotoxic Effects of Low-level Methylmercury contamination in the Amazonian Basin. Environ. Res. Oct; 79(1): 20-32.

LeBel, C. P., Ali, S. F., McKee, M., Bondy, S. C. (1990). Organometal-induced increases in oxygen reactive species: the potential of 2', 7'- dichlorofluorescin diacetate as an index of neurotoxic damage. Toxicol. Appl. Pharmacol. 104: 17-24.

Lebel, J., Mergler, D., Lucotte, M., Amorim, M., Dolbec, J., Miranda, D., Arantes, G., Rheault, I., Pichet, P. (1996). Evidence of Early Nervous System Dysfunction in Amazonian Populations Exposed to Low-levels of Methylmercury. Neurotoxicology. Spring; 17(1): 157- 67.

Lent, Roberto. Cem Bilhões de Neurônios: Conceitos Fundamentais de Neurociências. São Paulo: Atheneu, 2001.

Levine, J. S., MacNichol, E. F. JR. Visual Pigments in Teleost Fishes: Effects of Habitat, Microhabitat, and Behavior on Visual System Evolution. Sensory Processes. 3(2): 95-131. 1979. 
Liber, A, M, P., Oliveira, T, M. (2005). Neurofisiologia da Visão de Vertebrados: A Maquinaria Neuronal da Retina. Trabalho de Conclusão de Curso. TCC, Universidade do Grande ABC, Santo André.

Lima, S. M., Bonci, D. M. O., Grötzner, S. R., Ribeiro, C. A., Ventura, D. F. (2003). Loss of Amacrine Cells in MeHg-treated Retina in a Tropical Fish. Annual Meeting Abstract www.arvo.org. Association for Research in Vision and Ophthalmology (ARVO), Ft Lauterdale, Florida, Abstract 4551.

Lisney, T. J. \& Collin, S. P. (2008). Retinal ganglion cell distribution and spatial resolving power in elasmobranchs. Brain Behav Evol, 72: 59-77.

Lockshin, R, A,, Williams, C, M. (1964). Programmed cell death. II. Endocrine potentiation of the breakdown of the intersegmental muscles of silkmoths. $J$ Insect Physiol. 10: 643-649.

Lu, T. H., Hsieh, S.Y., Yen, C. C., Wu, H. C., Chen, K. L., Hung, D. Z., Chen, C. H., Wu, C. C., Su, Y. C., Chen, Y. W., Liu, S. H., Huang, C. F. (2011). Involvement of oxidative stress-mediated ERK1/2 and p38 activation regulated mitochondria-dependent apoptotic signals in methylmercury-induced neuronal cell injury. Toxicology Letters. 204: 71-80.

Lythgoe, F. N. (1991). Evolution of Visual Behavior. In: Vision and Visual Dysfunction: Evolution of the Eye and Visual System. Editores: John, R, Cronly-Dillon; Richard, L.; Gregory, Macmillan. Press Ltd., 2: 3-14.

Magalhães, A. C. (1931). Monografia Brasileira de Peixes Fluviais. P. 209-13. 
Mela, M. (2004). Uso de Biomarcadores na Avaliação dos Efeitos do Metilmercúrio em Hoplias malabaricus. Dissertação de Mestrado em Biologia Celular e Molecular, Universidade Federal do Paraná, Curitiba-PR.

Mela, M., Cambier, S., Mesmer-Dudons, N., Grotzner, S, R., Ribeiro, C, A, O., Ventura, D, F., Massabuau, J. (2010). Methylmercury distribution in Danio rerio retina determined by autometallography. Neurotoxicology (Park Forest South), v. 31, p. online may 5 .

Mela, M., Randi, M. A. F., Ventura, D. F., Carvalho, C. V., Pelletier, E., Ribeiro, C. A. O. (2007). Effects of dietary methylmercury on liver and kidney histology in the neotropical fish Hoplias malabaricus. Ecotoxicology and Environmental Safety. 68: 426 $-435$.

Mello, P. A. de A. (2001). Oftalmologia. Revista Racine. 8(44): 18-20.

Merigan, W. H. (1979). Effects of Toxicants on Visual Systems. Neurobehavioral Toxicology and Teratology. 1: 15-22.

Merigan, W. H., Maurissen, J. P., Weiss, B., et al. (1983). Neurotoxic Actions of Methylmercury on the Primate Visual System. Neurobehavioral Toxicology and Teratology. 5: 649-58.

Ni, M., Li, X.,Yin, z., Sidoryk-Węgrzynowicz, M., Jiang, H., Farina, M., Rocha, J. B. T., Syversen, T., Aschner, M. (2011). Comparative study on the response of rat primary astrocytes and microglia to methylmercury toxicity. Glia. May 59(5): 810-820.

NIH - Guide for the care and use of laboratory animals. National Academy Press. Washington, 1996. 
Negishi, K., Salas, R., Parthe, V., Drujan, B, D. (1988). Identification of Horizontal Cells Generating Different Spectral Responses in the Retina of a Teleost Fish (Eugerres plumieri). The Journal of Neuroscience Research. 20(2): 246-56.

Nelson, R., Kolb, H., Freed, M, A. (1993). Off-alpha and Off-beta ganglion cells in cat retina. Intracellular electrophysiology and HRP stains. J. Comp. Neurol. Mar1;329(1):68-84.

Nelson, R., Famiglietti, E, V., Kolb, H. (1978). Intracellular staining reveals different levels of stratification for on-centerand off-center ganglion cells in the cat retina. $J$. Neuropysiol. 4, 427-483.

Oga, S., Chasin, A. A., Machado-Santelli, G. M.. Fundamentos de toxicologia. São Paulo: Atheneu, 1996.

Oliveira-Ribeiro, C. A., Filipak Neto, F., Mela, M., Silva, P. H., Randi, M. A., Rabitto, I. S., Costa JR, A., Pelletier, E. (2006). Hematological Findings in Neotropical Fish Hoplias malabaricus Exposed to Subchronic and Dietary Doses of Methylmercury, Inorganic Lead, and Tributyltin Chloride. Environmental Research. 101(1): 74-80.

Okazaki, E., Oyama, Y., Chikahisa, L., Nagano, T., Katayama, N., Sakamoto, M. (1997). Fluorescent estimation on cytotoxicity of methylmercury in dissociated rat cerebellar neurons: its comparison with ionomycin. Environmental Toxicology and Pharmacology.3: 237-244.

Oliveira Ribeiro, C. A. ; Mesmer-Dudons, Gonzalez, P., Yannick, D., Bourdineaud, J., Boudou, A., Massabuau, J. C. (2008). Chronic and Trophic Effects of Methylmercury on Zebra fish Muscle Fibers. Environmental Toxicology and Pharmacology, 25: 304 305. 
Osborne, N. N., Barnett, N. L., Morris, N. J., Huang, F. L. (1992). The Occurrence of Three Isoenzymes of Protein Kinase C (Alpha, Beta and Gamma) in Retinas of Different Species. Brain Research. 570(1-2): 161-66.

Osborne, N. N., Broyden, N. J., Barnett, N. L., Morris, N. J. (1991). Protein kinase C (Alpha and Beta) Immunoreactivity in Rabbit and Rat Retina: Effect of Phorbol Esters and Transmitter Agonists on Immunoreactivity and the Translocation of the Enzyme From Cytosolic to Membrane Compartments. The Journal of Neurochemistry. 57(2): 594-04.

Oyama, Y., Tomiyoshi, F., Ueno, S., Furukawa, K., Chikahisa, L. (1994). methylmercury-induced augmentation of oxidative-metabolism in cerebellar neurons dissociated from the rats - its dependence on intracellular ca2 ${ }^{+}$. Brain Research. 660 (1): 154-157.

Parry, J. W., Carleton, K. L., Spady, T., Caoboo, A., Hunt, D. M., Bowmaker, J. K. (2005). Mix and Match Color Vision: Tuning Spectral Sensitivity by Differential Opsin Gene Expression in Lake Malawi Cichlids. Current Biology. 15(19): 1734-39.

Pettigrew, J. D., Dreher, B., Hopkins, C. S., McCall, M. J. \& Brown, M. (1988). Peak density and distribution of ganglion cells in the retinae of microchiropteran bats: implications for visual acuity. Brain Behav Evol, 32: 39-56.

Pettigrew, J.D. \& Manger, P.R. (2008). Retinal ganglion cell density of the black rhinoceros (Dicero bicornis): calculating visual resolution. Visual Neuroscience, 25: 215-220.

Piccolino, M. (1988). Cajal and The Retina: A 100 - Year Retrospective. Tins, v.11 (12). 
Pointer, M. A., Cheng, C. H., Bowmaker, J. K., Parry, J. W., Soto, N., Jeffrey, G., Cowing, J. A., Hunt, D. M. (2005). Adaptations to an Extreme Environment: Retinal Organization and Spectral Properties of Photoreceptors in Antarctic Notothenioid Fish. The Journal of Experimental Biology. 2363-76.

Pointer, M. A., Cheng, C. H., Bowmaker, J. W., Soto, N., Jeffery, G., Cowing, J. A., Hunt, D. M. (2005). Adaptations to an extreme environment: retinal organization and spectral properties of photoreceptors in Antarctic notothenioid fish. J. Exp. Biol. Jun;208 (Pt 12): 2363-2376.

Prodocimo, M. M. (2009). Avaliação dos efeitos tóxicos do metilmercúrio na retina de duas espécies de teleósteos: Hoplias malabaricus e Danio rerio, utilizando um conjunto de biomarcadores biológicos. Tese de doutorado, Instituto de Psicologia, Universidade de São Paulo, São Paulo.

Rapaport D. H, Stone J. (1984). The area centralis of the retina in the cat and other mammals: focal point for function and development of the visual system. Neuroscience. Feb; 11(2): 289-301.

Reckel, F., Melzer, R, R., Parry, J, W., Bowmaker, J, K. (2002). The Retina of Five Atherinomorph Teleosts: Photoreceptors, Patterns and Spectral Sensitivities. Brain Behavior and Evolution. 60(5): 249-64.

Rice, D. C., Gilbert, S. G. (1992). Exposure to Methyl Mercury From Birth to Adult Hood Impairs High-frequency Hearing in Monkeys. Toxicology and Applied Pharmacology. 115(1): 6-10. 
Rocha, F. A. F. (2002). Caracterização de Fotorreceptores na Retina da Cutia, Dasyprocta agouti. Dissertação de Mestrado, Centro de Ciências Biológicas II, Universidade Federal do Pará, Pará.

Rollag M. D, Berson D. M, Provencio I. (2003). Melanopsin, ganglion-cell photoreceptors, and mammalian photoentrainment. J Biol Rhythms.18:227-34.

Roulet, M., Lucotte, M., Farella, N., Serique, G., Coelho, H., Passos, S. C. I., Silva, E. de Jesus, da Silva, de Andrade, P., Mergler, D., Guimarães, J. R. D., Amorim, M. (1998). Effects of Recent Human Colonization on the Presence of Mercury in Amazonian Ecosystems. Water, Air and Soil Pollution. 112(3-4): 297-13.

Feitosa-Santana, C. (2006). Reconstrução do Espaço de Cores de Pacientes com Discromatopsia Adquirida: Diabéticos tipo 2 e Intoxicados por Vapor de Mercúrio. Dissertação de Mestrado, Instituto de Psicologia, Universidade de São Paulo. São Paulo. Sarafian, T. A. (1993). Methyl Mercury Increases Intracellular Ca2+ and Inositol Phosphate Levels in Cultured Cerebellar Granule Neurons. J. Neurochem. 61(2): 648 657.

Sarafian, T. A., Vartavarian, L., Kane, D. J., Bredesen, D. E., Verity, M. A. (1994). bcl2 expression decreases methyl mercury-induced free-radical generation and cell killing in a neural cell line. Toxicology Letters. Nov 74(2):149-155

Sarafian, T., Verity, M. A. (1991). Oxidative mechanisms underlying methyl mercury neurotoxicity. International Journal of Developmental Neuroscience. 9 (2): 147-153.

Sakamoto, M., Nakano, A. \& Akagi, H. 2000. Diclining Minamata male birth ratio associated with increased male fetal death due to heavy methylmercury. Pollution. Environ. Res. 87: 92-98. 
Schein, S. J. (1988). Anatomy of macaque fovea and spatial densities of neurons in foveal representation. J. Comp. Neurol. 269, 479-505.

Seiler, H. G., Sigel, H. Handbook on Toxicity of Inorganic Compounds. New York: Dekker, 1988.

Silveira, L, C, L., Damin, E, T, B., Pinheiro, M, C, N., Rodrigues, A, R., Moura, A, L, A., Mello, G, A. (2003). Visual Dysfunction Following Mercury Exposure By Breathing Mercury Vapour or By Eating Mercury-Contaminated Food. In: J. D.Mollon, J. Pokorny, K. Knoblauch (Eds.). Normal and Defective Colour Vision. Oxford: Oxford University Press.

Silveira, L. C. L., Ventura, D. F., Pinheiro, M. C. N. (2004). Toxicidade Mercurial Avaliação do Sistema Visual em Indivíduos Expostos a Níveis Tóxicos de Mercúrio. Revista Ciência e Cultura. 56(1): 36-38.

Simões, A. L. A. C. (2004). Estudo das Alterações Visuais Cromáticas em Trabalhadores Expostos ao Vapor de Mercúrio. Dissertação de Mestrado. Instituto de Psicologia, Universidade de São Paulo, São Paulo.

Smith, G. \& Atchison, D. A. (1997). The Eye and Visual Optical Instrument. New York: Cambridge University Press.

Snyder, A.W. \& Miller, W.H. (1977). Photoreceptor diameter and spacing for highest resolving power. J Opt Soc Am, 67: 696-698.

Suzuki, S., Kaneko, A. (1990). Identification of Bipolar Cell Subtypes By Protein Kinase C-like Immunoreactivity in the Goldfish Retina. Visual Neuroscience. 5(3): 22330. 
Sherry, D, M., Yazulla, S. (1993). Goldfish Bipolar Cells and Axon Terminal Patterns: A Golgi Study. The Journal of Comparative Neurology. 329(2): 188-00.

Shimbo, K., Toyoda, J. I., Kondo, H., Kujiraoka, T. (2000). Color-opponent responses of small and giantbipolar cells in the carp retina. Vis. Neurosci. Jul-Aug;17(4):609-21.

Shin, T., Kim, S., Ahn, M., Kim, H. (2006). An immunohistochemical study of protein kinase C in the bovine retina. The Journal of Veterinary Medical Science, 68(1): 71-74.

Sura, P., Bronowicka-Adamska, P., Furtak, E., Wróbel, M. (2011). Effect of mercury ions on cysteine metabolism in Xenopus laevis tissues. Comparative Biochemistry and Physiology, Part C. 154: 180-186.

Taub, A., Zachi, E. C., Teixeira, R. A. A., Ventura, D. F. (2006). A aplicação da Neuropsicologia na pesquisa experimental: o exemplo da intoxicação por vapor de mercúrio. Psicologia USP. 17(4): 289 - 302.

Tanaka, C., Nishizuka, Y. (1994). The Protein Kinase C Family for Neuronal Signaling. Annuals Reviews in Neuroscience. 17: 551-67.

Tanan, C. L., ventura, D. F., de Souza, J. M., Grötzner, S. R., Mela, M., Gouveia JR, A., Oliveira-Ribeiro, C. A. (2006). Effects of Mercury Intoxication on the Response of Horizontal Cells of the Retina of Thraira Fish (Hoplias malabaricus). Brazilian Journal of Medical and Biological Research. 39(7): 987-95.

Tachibana, M. (1999). Regulation of Transmitter Release From Retinal Bipolar Cells. Progress in Biophysics Molecular Biology. 72(2): 109-33.

Takashima, F. \& Hibiya, T. 1998. Na Atlas of fish histology: normal and pathological features. Second edition. 121p. 
Tessier-Lavigne, M.., Mobbs, P., Attwell, D. (1985). Lead and Mercury Toxicity and the Rod Light Response. Investigative ophthalmology \& Visual Science. 26: 1117-23.

Tootell, R. B. H., Hamilton, S. L., Switkes, E. (1988). Functional Anatomy of Macaque Striate Cortex. IV. Contrast and Magno-Parvo Streams. The Journal of Neuroscience. 8(5): 1594-1 609.

Umino, Y., Niino, M., Saito, T. (2003). Morphological and Functional Organization of ON and OFF Pathways in the Adult Newt Retina. Zoological Science. 20(3): 291-01.

Urban, P., Gobba, F., Nerudova, J., Lukas, E., Cabelkova, Z., Cikrt, M. (2003). Color Discrimination Impairment in Workers Exposed to Mercury Vapor. Neurotoxicology. 24(4-5): 711-16.

Usuda, N., Kong, Y., Hagiwara, M., Uchida, C., Terasawa, M., Nagata, T., Hidaka, H. (1991). Differential Localization of Protein Kinase C Isozymes in Retinal Neurons. The Journal of Cell Biology. 112(6): 1241-47.

Usuki, F., Yamashita, A., Fujimura, M. (2011). Post-transcriptional Defects of Antioxidant Selenoenzymes Cause Oxidative Stress under Methylmercury Exposure. The Journal Of Biological Chemistry. 286 (8):6641-6649.

Vaquero, C. F., Velasco, A., de La Villa, P. (1997). Quantitative Measurement of Protein Kinase C Immunoreactivity in Rod Bipolar Cells of The Goldfish Retina. Brain Research. 773(1-2): 208-12.

Van Der Meer, H. J. (1995). Visual resolution during growth in a cichlid fish: A morphological and behavioral case study. Brain, Behavior and Evolution, 45: 25-33. 
Vimercati, L., Santarelli, L., Pesola, G., Drago, I., Larosa, G., Valentino, M., Vacca, A., Soleo, L. (2001). Monocyte-macrophage System and Polymorphonuclear Leukocytes in Workers Exposed to Low levels of Metallic Mercury. The Science of the Total Environment. 270(1-3): 157-63.

Ventura, D. F., Costa, M. T., Costa, M. F., Berezovsky, A., Salomão, S, R., Simões, A, L., Lago, M., Pereira, L, H., Faria, M, A., de Souza, J, M., Silveira, L, C, L. (2004). Multifocal and Full-field Electroretinogram Changes Associated With Color-vision Loss in Mercury Vapor Exposure. Visual Neuroscience. 21(3): 421-29.

Ventura, D. F., Simões, A. L., Canto-Pereira, L. H. M., Tomaz, S. Lago, M., Costa, M, T, V., Costa, M, F., Souza, J. M., Faria, M. A. M., Silveira, L. C. L. (2005). Color Vision and Contrast Sensitivity Losses of Mercury Contaminated Industry Workers in Brazil. Environmental toxicology and pharmacology. 19(3): 523- 29.

Ventura, D. F., Simões, A. L, Costa, M, F., Costa, M. T. V., de Souza, J. M, Canto-, Pereira, L. H. M., Lago, M., Faria, M, A, M., Silveira, L. C. L. (2003a). Hue and Saturation Discrimination and Electroretinograms of Mercury Contaminated Industry Workers in Brazil. Proceedings of the 9th Meeting of the International Neurotoxicology Association (INA).

Ventura, D. F., Berezovsky, A., Salomão, S. R., Costa, M T. V., Simões, A, L., CantoPereira, L. M., Costa, M. F., de Souza, J, M., Lago, M., Faria, M. A. M., Silveira, L. C. L. (2003b). Multifocal Electroretinograms (mfERGs) Correlate With Color Vision Losses in Mercury Contaminated Workers. Proceedings of the 17th Symposium of the International Color Vision Society (ICVS).

Ventura, D. F., Simões, A. L., Costa, M. T. V., Costa, M, F., de Souza, J, M., CantoPereira, L, H, M., Lago, M., Faria, M. A. M., Silveira, L. C. L. (2003c). Occupational 
Mercury Contamination Produces Loss of Color-and Contrast-vision But No Effect in Full Field ERG. Annual Meeting Abstract www.arvo.org. Association for Research in Vision and Ophthalmology (ARVO), Abstract 4112.

WHO (World Health Organization), IPCS (International Program in Chemical Safety). (1990). Environmental Health Criteria 101 Methylmercury. World Health Organization, Geneva, Switzerland.

Wagner, H. J, Fröhlich, E., Negishi, K. \& Collin, S.P. (1998). The eyes of deep-sea fish. II. Functional morphology of the retina. Prog Retin Eye Res, 17: 637-685.

Warfvinge, K. (2000). Mercury Distribution in the Neonatal and an Adult Cerebellum After Mercury Vapour Exposure of Pregnant Squirrel Monkeys. Environ. Res. Jun; 83(2): 93-01.

Warfvinge, K. \& Bruun, A. (1996). Mercury accumulation in the squirrel monkey eye after mercury vapour exposure. Toxicology, 107(3): 189-200.

Warfvinge, K. \& Bruun, A. (2000). Mercury distribution in the squirrel monkey retina after in Utero exposure to mercury vapor. Environmental Research, 83(2): 102-109.

Werblin, F. S., Dowling, J. E. (1969). Organization of the retina of the mudpuppy, Necturus maculosus. II. Intracellular recording. J. Neurophysil.May;32(3):339-55.

Wong, R. O .L. \& Hughes, A. (1987). The morphology, number, and distribution of a large population of confirmed displaced amacrine cells in the adult cat retina. Journal of Comparative Neurology, 255: 159-177.

Zachi, E. C., Taub, A., Faria, M. A. M., Ventura, D. F. (2008). Neuropsychological alterations in mercury intoxication are retained after several after several years away 
from exposure. Dementia \& Neuropsychologia. 2: 91 - 95.

Zhang, D. R., Yeh, H. H. (1991). Protein kinase C-like Immunoreactivity in Rod Bipolar Cells of the Rat Retina: A Developmental Study. Visual Neuroscience. 6(5): 429-37.

Yee, S., Choi, B. H. Methylmercury poisoning induces oxidative stress in the mouse brain. Exp. Mol. Pathol. 60 (1994): 188-196.

Zhang, L., Dekorver, L., Kolb, H. (1992). Immunocytochemical Staining With Antibodies Against Protein Kinase C and its Isozymes in the Turtle Retina. The Journal of Neurocytology. 21(12): 833-45. 
Anexos 
Anexo 01

Carta de aceite do comitê de ética:

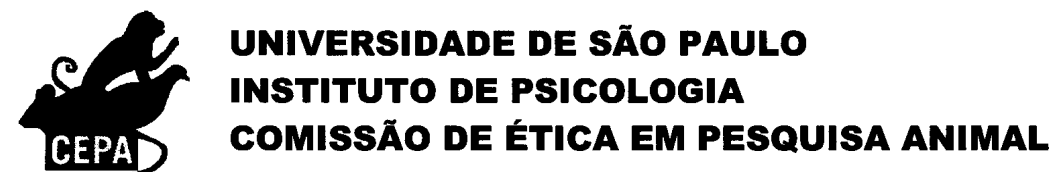

\section{CERTIFICADO}

Certificamos que o projeto intitulado Análise das Células Bipolares PKC-IR da Retina de Peixe Tropical Hoplias malaricus Intoxicado com baixa doses Agudas e Subcrônicas de Metilmercúrio, sob a responsabilidade de Marcelo Fernandes da Costa e André Maurício Passos Liber, foi aprovado pela COMISSÃo dE ÉTICA EM PESQUISA ANIMAL DO INSTITUTO DE PSICOLOGIA.

São Paulo, 25 de março de 2008.

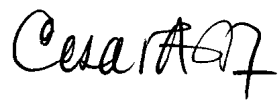

Prof. Dr. César Ades Presidente - CEPA

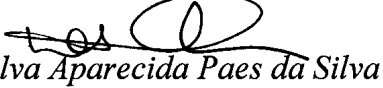

Secretária 


\section{Anexo 02}

Bateria de coloração da técnica de Nissl utilizada:

Solução Sanduíche - formalina 10\% (1: 9 - formol /solução salina 0,9\%).

Deixar sanduíche mergulhado em formalina por 2 horas.

Em seguida passar pela seguinte bateria:

○ $\quad 3$ min. Álcool 95\%

○ $\quad 3$ min. Álcool $70 \%$

○ $\quad 3$ min. Álcool $50 \%$

- D-H2O

- Cresil violeta $0,3 \%$ - tempo varia de acordo com material

○ 3 mergulhos D-H2O

○ $\quad 3$ min. Álcool $70 \%$

○ (constratação) 3 min. Álcool 95\% + ác. Acético (3gts - varia c/ volume)

○ $\quad 3$ min. Álcool 95\%

○ $\quad 3$ min. Álcool $100 \%$

○ $\quad 3$ min. Álcool $100 \%$

○ $\quad 3$ min. Álcool butílico

○ $\quad 3 \mathrm{~min}$. Álcool + xilol (1:1)

○ $\quad 3$ min. xilol I

○ $\quad 3$ min. xilol II 